AperTO - Archivio Istituzionale Open Access dell'Università di Torino

\title{
Local Proton Source in Electrocatalytic CO2 Reduction with [Mn(bpy-R)(CO)3Br] Complexes
}

\section{This is a pre print version of the following article:}

Original Citation:

\section{Availability:}

This version is available http://hdl.handle.net/2318/1633130

since 2017-05-11T16:26:36Z

Published version:

DOI:10.1002/chem.201605546

Terms of use:

Open Access

Anyone can freely access the full text of works made available as "Open Access". Works made available under a Creative Commons license can be used according to the terms and conditions of said license. Use of all other works requires consent of the right holder (author or publisher) if not exempted from copyright protection by the applicable law. 


\title{
Local Proton Source in the Electrocatalytic $\mathrm{CO}_{2}$ Reduction by $\mathrm{Mn}(\mathrm{bpy}-\mathrm{R})(\mathrm{CO})_{3} \mathrm{Br}$ Complexes
}

\author{
Federico Franco ${ }^{[a] \$}$, Claudio Cometto ${ }^{[a, c] \$}$, Luca Nencini ${ }^{[a] \$}$, Claudia Barolo ${ }^{[a]}$, Fabrizio Sordello ${ }^{[a]}$, \\ Claudio Minero ${ }^{[a]}$, Jan Fiedler ${ }^{[b]}$, Marc Robert ${ }^{[c]}$, Roberto Gobetto*[a] and Carlo Nervi ${ }^{*[a]}$
}

\begin{abstract}
The electrochemical behavior of fac-[Mn(pdbpy) $\left.(\mathrm{CO})_{3} \mathrm{Br}\right]$ (pdbpy = 4-phenyl-6-(phenyl-2,6-diol)-2,2'-bipyridine), 1, in acetonitrile under $\mathrm{Ar}$ and its catalytic performances for $\mathrm{CO}_{2}$ reduction with added water, 2,2',2"-trifluoroethanol (TFE) and phenol are discussed in detail. Preparative-scale electrolysis experiments, carried out at $-1.5 \mathrm{~V}$ vs. SCE in $\mathrm{CO}_{2}$-saturated acetonitrile solutions, reveal that the process selectivity is extremely sensitive to the acid strength, providing $\mathrm{CO}$ and formate in different faradaic yields. A detailed spectroelectrochemical (IR and UV-Vis) study under Ar and $\mathrm{CO}_{2}$ atmospheres shows that 1 undergoes fast solvolysis; however dimer formation in acetonitrile is suppressed, providing an atypical reduction mechanism in comparison with other reported $\mathrm{Mn}^{\prime}$ catalysts. Spectroscopic evidence of Mn hydride formation supports the existence of different electrocatalytic $\mathrm{CO}_{2}$ reduction pathways. Furthermore, a comparative investigation performed on the new fac$\left[\mathrm{Mn}\right.$ (ptbpy) $\left.(\mathrm{CO})_{3} \mathrm{Br}\right]$ (ptbpy = 4-phenyl-6-(phenyl-3,4,5-triol)-2,2'bipyridine) catalyst, 2, bearing a bipyridyl derivative with $\mathrm{OH}$ groups in different positions to those in 1 , provides complementary information about the role that the local proton source plays during the electrochemical reduction of $\mathrm{CO}_{2}$.
\end{abstract}

\section{Introduction}

The electrochemical conversion of carbon dioxide into valueadded chemicals mediated by transition metal complexes has attracted growing interest in recent years. ${ }^{[1-2]}$ The rational design of molecular catalysts that possess low overpotentials for the selective conversion of $\mathrm{CO}_{2}$ is a crucial target, while knowledge of the main factors affecting this process will provide the basis for future improvements and advances in this field. Many organometallic catalysts have been found to selectively reduce $\mathrm{CO}_{2}$ into such two-electron products as $\mathrm{CO}$ and $\mathrm{HCOOH}$ in nonaqueous systems. The former is widely used in mixtures with $\mathrm{H}_{2}$ (syngas) in large-scale industrial processes. ${ }^{[3]}$ Liquid solutions of formic acid can instead be directly used in green technologies (fuel cells), ${ }^{[4]}$ or as hydrogen storage materials. ${ }^{[5]}$ However, most of the reported homogeneous catalysts for $\mathrm{CO}_{2}$ electrochemical reduction are selective towards $\mathrm{CO}$ formation, ${ }^{[2,6]}$ whereas only a few of them give formate in high yields. ${ }^{[7]}$

[a] Dr. F. Franco, C. Cometto, L. Nencini, Prof. Dr. C.Barolo, Dr. F. Sordello, Prof. Dr. C. Minero, Prof. Dr. C. Nervi and Prof. Dr. R. Gobetto.

University of Turin, Department of Chemistry and NIS, Via P. Giuria 7, 10125 Turin, Italy, E-mail: carlo.nervi@unito.it

$\$ \quad$ These authors equally contributed.

[b] Ing. CSc. J.Fiedler,

Heyrovský Institute of Physical Chemistry of ASCR, v.v.i. Dolejškova 3, 18223 Prague, Czech Republic

[c] Prof. Dr. M. Robert., C. Cometto

Univ. Paris Diderot, Sorbonne Paris Cité, UMR CNRS 7591, Laboratoire Electrochimie Moléculaire, F-75205 Paris 13, France

Supporting information for this article is given via a link at the end of the document. fac- $\left[\mathrm{M}(\right.$ bpy- $\left.\mathrm{R})(\mathrm{CO})_{3} \mathrm{X}\right](\mathrm{M}=\mathrm{Mn}$ ', Re'; bpy-R = 2,2'-bipyridinebased ligands; $X=\mathrm{Cl}^{-}$or $\mathrm{Br}^{-}$) complexes have been widely studied as precursors to efficient electrocatalysts for the reduction of $\mathrm{CO}_{2}$ to $\mathrm{CO}$. In particular, $\mathrm{Mn}$ complexes bearing 4,4'-disubstituted bipyridines with $\mathrm{H}, \mathrm{CH}_{3}$ and $t$-Bu (since all complexes herein mentioned are fac- we will omit this label) are valid low-cost alternatives to the $\mathrm{Re}^{\prime}$ counterparts in terms of stability, selectivity and efficiency. ${ }^{[8]}$ The combination of IR/UVVis spectroelectrochemistry (SEC) ${ }^{[9]}$ with non-conventional spectroscopic techniques ${ }^{[10-12]}$ and computational methods, ${ }^{[13]}$ provided valuable complementary tools to electrochemistry for elucidating the electrocatalytic mechanism of $\mathrm{CO}_{2}$ reduction by Group VII metal based catalysts. These studies suggest that doubly reduced pentacoordinated species $\left[\mathrm{M}(\mathrm{bpy}-\mathrm{R})(\mathrm{CO})_{3}\right]^{-}(\mathrm{M}$ $=\mathrm{Mn}, \mathrm{Re}$ ) are responsible for the catalytic conversion of $\mathrm{CO}_{2}$ into CO. Nevertheless, there are several differences in the electrocatalytic behavior of the two classes of complexes. The $\mathrm{Mn}$ catalysts are formed upon the reductive cleavage of the $\left[\mathrm{Mn}(\mathrm{bpy}-\mathrm{R})(\mathrm{CO})_{3}\right]_{2}$ dimer, which is generated after the $1 \mathrm{e}$ reduction of the starting species and subsequent rapid dissociation of the halogen ion. Contrariwise, the structurally similar $\left[\mathrm{Re}(\text { bpy- } \mathrm{R})(\mathrm{CO})_{3}\right]_{2}$ dimer is known to be a side-product in the electrocatalytic cycle of $\mathrm{Re}$ complexes. ${ }^{[14]}$ In an effort to reduce the overpotential required for the formation of the catalytically active species, Kubiak and coworkers have recently exploited the bulky nature of the mesbpy ligand (6,6'-dimesityl2,2'-bipyridine) to prevent dimerization in [Mn(mesbpy)$\left.(\mathrm{CO})_{3} \mathrm{Br}\right] .^{[15]}$ However, the $\left[\mathrm{Mn}(\right.$ mesbpy $\left.)(\mathrm{CO})_{3}(\mathrm{COOH})\right]$ adduct requires a third "extra-electron" and catalysis occurs more negatively even though the $\left[\mathrm{Mn}(\text { mesbpy })(\mathrm{CO})_{3}\right]^{-}$anion is formed via a $2 e$ transfer (ECE mechanism) at less negative potentials than in the case of bpy. Moreover, unlike the polypyridyl $\mathrm{Re}$ catalysts, Mn-based catalytic $\mathrm{CO}_{2}$ conversion is commonly observed only in the presence of an added proton source (water, methanol or TFE). ${ }^{[8,15]}$ Nevertheless, we have recently reported the first case of a bromotricarbonyl $\mathrm{Mn}^{\prime}$ catalyst, namely [Mn(pdbpy) $\left.(\mathrm{CO})_{3} \mathrm{Br}\right](1)$ that is capable of reducing $\mathrm{CO}_{2}$ even in anhydrous acetonitrile, ${ }^{[16]}$ without the need for deliberate addition of Brønsted acids. ${ }^{[17]}$ This unique behavior has been ascribed to the structure of the pdbpy ligand, in which the pendant phenolic groups near to the metal center may act as intramolecular proton sources (Figure 1). We found that the presence of local protons not only provided a dramatic enhancement in the electrocatalytic activity towards $\mathrm{CO}_{2}$ reduction, but also an unexpected change in selectivity, producing a non-negligible amount of formate in addition to $\mathrm{CO}$. Two distinct pathways have therefore been proposed along with the formation of an electroinduced Mn hydride species, which was assumed to be responsible for $\mathrm{HCOO}^{-}$production, as reported in recent photocatalytic studies on $\left[\mathrm{Mn}(\mathrm{bpy})(\mathrm{CO})_{3} \mathrm{Br}\right] .{ }^{[18,19]}$

Encouraged by the remarkable electrocatalytic activity of $\mathbf{1}$ under $\mathrm{CO}_{2}$, we firstly aimed to in-depth investigate its unusual electrochemical behavior under inert atmosphere by using cyclic voltammetry (CV) and IR/UV-Vis SEC. 


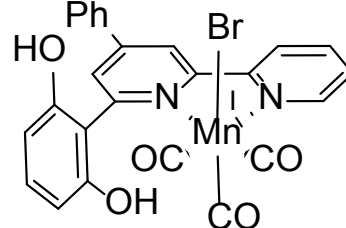

$\mathrm{Mn}^{\mathrm{I}}(\mathrm{pdbpy})(\mathrm{CO})_{3} \mathrm{Br}$

(1)

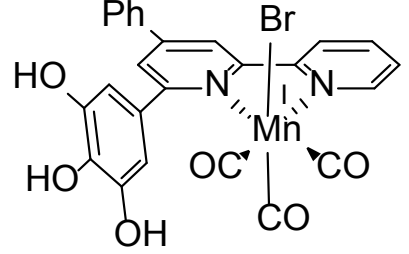

$\mathrm{Mn}^{\prime}($ ptbpy $)(\mathrm{CO})_{3} \mathrm{Br}$

(2)
Figure 1. Chemical sketches of the complex 1 and 2.

Furthermore, the effect due to the addition of different proton sources $\left(\mathrm{H}_{2} \mathrm{O}\right.$, TFE and phenol) on either the electrocatalytic activity and selectivity of 1 under $\mathrm{CO}_{2}$ was also evaluated. Finally, a comparative study on the structurally similar $\left[\mathrm{Mn}\right.$ (ptbpy) $\left.(\mathrm{CO})_{3} \mathrm{Br}\right](2)$, containing three local $\mathrm{OH}$ groups in meta and para positions of the phenolic ring in 6 , i.e. a little farther from the Mn center than in 1 (Figure 1), provided further useful information to better understand the role of an intramolecular proton source on the electrochemical and electrocatalytic properties of this class of catalysts.

\section{Results and Discussion}

Synthesis and characterization. The pdbpy and ptbpy ligands were synthesized using the Kröhnke reaction and by coupling the corresponding pyridinium iodides and chalcones according to the reported procedure ${ }^{[17]} \mathrm{A}$ demethylation reaction, based on refluxing the precursor in a $\mathrm{CH}_{3} \mathrm{COOH}$ solution of $\mathrm{HBr}(33 \%)$, was used to synthesize the final ptbpy ligand. Full details can be found in the Experimental Section.

Cyclic voltammetry (CV) under Ar. CV of complex 1 in MeCN under inert atmosphere ${ }^{[17]}$ exhibits three consecutive reduction waves (Figures 2 and S1). The first two reduction processes, R1 and $\mathrm{R} 2$, are chemically irreversible $\left(E_{p}=-1.21 \mathrm{~V},-1.50 \mathrm{~V} v \mathrm{v}\right.$. SCE), whereas the third reduction R3 appears to be quasireversible $\left(E_{1 / 2}=-1.66 \mathrm{~V}\right)$. R2 and $\mathrm{R} 3$ current peaks decrease with respect to R1 (Figure S2) upon increasing the scan rate. This is consistent with a mechanism in which chemical processes following R1 generate the species undergoing the reductions $\mathrm{R} 2$ and $\mathrm{R} 3$.

As we will discuss later, the SEC experiments performed under Ar highlighted two key aspects that strongly influence the electrochemical behavior of $\mathbf{1}$ in MeCN. First of all, rapid solvolysis of the $\mathrm{Mn}-\mathrm{Br}$ bond even occurs at open circuit in the dark at room temperature. This behavior has been reported for similar complexes. ${ }^{[20-21]}$ Solutions of 1 in $\mathrm{MeCN}$ are thus mixtures of 1 and the positively charged $\left[\mathrm{Mn}(\mathrm{pdbpy})(\mathrm{CO})_{3^{-}}\right.$ $(\mathrm{MeCN})]^{+}$(1a). Moreover, the dimerization of $\mathbf{1}$ was not spectroscopically detected by IR and UV-Vis SEC upon R1 (see below). This is in agreement with $\mathrm{CV}$, where no anodic reoxidation peak of the dimer, commonly found at around -0.3 $\mathrm{V}^{\left[{ }^{[8]}\right.}$ is observed (Figure S1). Thus, the first reduction is chemically irreversible, but no dimer is formed. Exhaustive experiments under Ar performed just after R1 (-1.25 V vs. SCE) consumed one electron per molecule of 1 . More information about the chemical processes involved in the course of R1 will be given below.

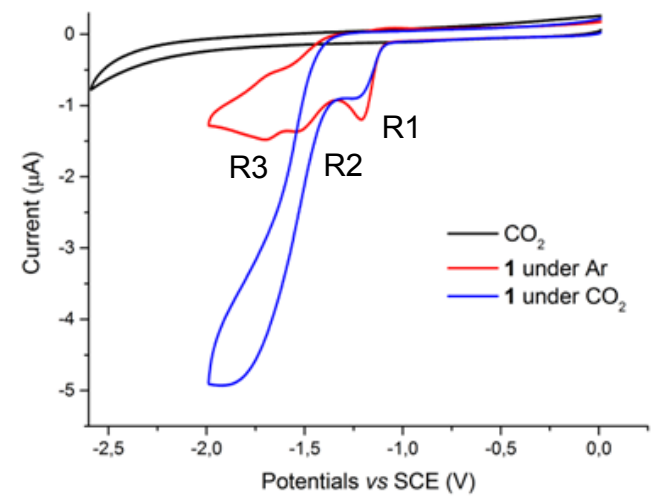

Figure 2. $\mathrm{CVs}$ of a MeCN solution of $1\left(0.5 \mathrm{mM}\right.$ ) at $100 \mathrm{mV} \mathrm{s}^{-1}$ under $\mathrm{Ar}$ (red curve) and $\mathrm{CO}_{2}$ (blue curve), at a glassy carbon electrode. The black line is the $\mathrm{CO}_{2}$-saturated blank.

Conversely, CV of 2 in MeCN under Ar significantly differs from that of 1 (Figure 3), resembling that of the well-known $\left[\mathrm{Mn}(\mathrm{bpy})(\mathrm{CO})_{3} \mathrm{Br}\right] .^{[8]}$ It exhibits a first irreversible reduction, R1', at $E_{p}=-1.30 \mathrm{~V}$, followed by fast $\mathrm{Br}^{-}$dissociation and the subsequent formation of the $\mathrm{Mn}-\mathrm{Mn}$ dimer, which is then reoxidized at $-0.49 \mathrm{~V}(\mathrm{O} 1$ ', Figure 3$)$. As evidenced by the IRSEC data (see below) the replacement of $\mathrm{Br}^{-}$by $\mathrm{MeCN}$ at open circuit is much slower in $\mathbf{2}$

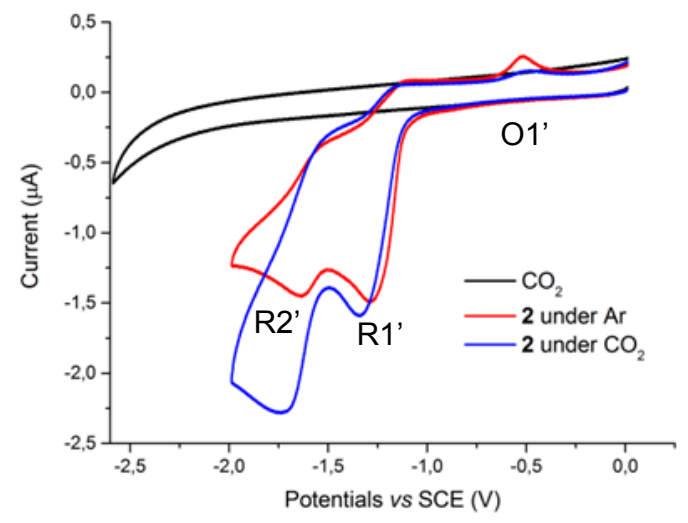

Figure 3. CVs of a MeCN solution of $2(0.5 \mathrm{mM})$ at $100 \mathrm{mV} \mathrm{s}^{-1}$ under $\mathrm{Ar}$ (red curve) and $\mathrm{CO}_{2}$ (blue curve), at a glassy carbon electrode. The black line is the $\mathrm{CO}_{2}$-saturated blank.

The second irreversible reduction of 2, R2', occurs more negatively, at $E_{p}=-1.64 \mathrm{~V}$. The relationship between the peak current of R2' and the CV scan rate is similar to findings for waves R2 and R3 in 1 (Figure S3). In a $1 \mathrm{mM}$ solution the apparent single R2' peak splits into two almost overlapped 
peaks that are ca. $70 \mathrm{mV}$ separated from each other $\left(E_{p}=-1.61\right.$ and $-1.68 \mathrm{~V}$, respectively) (Figure $\mathrm{S} 4$ ). The $\mathrm{Mn}$ catalyst containing the 6-(2-hydroxyphenyl)-2,2'-bipyridyl ligand showed an analogous $\mathrm{CV}$ response in $\mathrm{MeCN}+5 \% \mathrm{H}_{2} \mathrm{O}$, but the nature of the two reductions (at about $-1.30 \mathrm{~V}$ in that case) was not explained. ${ }^{[22]}$ They might be related to the presence of partially deprotonated intermediate species in solution which may be formed in the course of the reductive scan on the CV timescale. Further discussion of this point is given below.

\section{Infrared Spectroelectrochemistry (IR-SEC) under Ar and DFT calculations of $\mathbf{v}_{\mathrm{co}}$ stretches.}

IR-SEC of 1 in MeCN/TBAPF 6 . IR-SEC experiments were performed in an OTTLE cell in order to get further insights about the reduction paths of $\mathbf{1}$ and $\mathbf{2}$. This technique has already been used to characterize key intermediates during the electrochemical reduction of carbonyl organometallic electrocatalysts by monitoring the spectral changes of the $\mathrm{CO}$ stretching bands, $\mathrm{v}_{\mathrm{co}}{ }^{\left[{ }^{9]}\right.} \mathrm{DFT}$ calculations were employed as an additional tool to support the assignment of the intermediate species observed during the IR-SEC experiments.

Table 1. Selected experimental and calculated $\mathrm{v}_{\mathrm{CO}}$ in $\mathrm{MeCN}$.

\begin{tabular}{|c|c|c|}
\hline Complex & Experimental & $\mathbf{D F T}^{]}$ \\
\hline$\left[\mathrm{Mn}(\mathrm{pdbpy})(\mathrm{CO})_{3} \mathrm{Br}\right](\mathbf{1})$ & 2026, 1935, 1925(sh) & $2013,1939,1928$ \\
\hline$\left[\mathrm{Mn}(\mathrm{pdbpy})(\mathrm{CO})_{3}(\mathrm{MeCN})\right]^{+}(\mathbf{1 a})$ & 2044,1961 & 2033, (1962, 1951) \\
\hline$\left[\mathrm{Mn}(\mathrm{pdbpy})(\mathrm{CO})_{3} \mathrm{Br}\right]^{-}$ & & 1984, 1911, 1900 \\
\hline$\left[\mathrm{Mn}(\mathrm{pdbpy})(\mathrm{CO})_{3}(\mathrm{MeCN})\right]$ & & $2014,1938,1926$ \\
\hline$\left[\mathrm{Mn}\left(\mathrm{pdbpy}-\mathrm{H}^{+}\right)(\mathrm{CO})_{3}\right](\mathbf{1 b})$ & $2021,1920(\mathrm{br})$ & 2010, $(1925,1916)$ \\
\hline$\left[\mathrm{HMn}\left(\mathrm{pdbpy}-\mathrm{H}^{+}\right)(\mathrm{CO})_{3}\right]^{-}(\mathbf{1 c})$ & 1987, 1899, 1878(sh) & $1972,1891,1879$ \\
\hline$\left[\mathrm{HMn}(\mathrm{pdbpy})(\mathrm{CO})_{3}\right]\left(\mathbf{1} \mathrm{c}^{\prime}\right)$ & & $1988,1908,1897$ \\
\hline$\left[\mathrm{Mn}\left(\mathrm{pdbpy}-\mathrm{H}^{+}\right)(\mathrm{CO})_{3}\right]^{2-}(\mathbf{1 d})$ & $1910,1818(\mathrm{br})$ & $1892,(1832,1808)$ \\
\hline$\left[\mathrm{Mn}\left(\mathrm{pdbpy}-2 \mathrm{H}^{+}\right)(\mathrm{CO})_{3}\right]^{-}(\mathbf{1 e})$ & $2012,1916,1900(\mathrm{sh})$ & $1998,1912,1899$ \\
\hline$\left[\mathrm{Mn}\left(\mathrm{pdbpy}-2 \mathrm{H}^{+}\right)(\mathrm{CO})_{3}\right]^{3-}(\mathbf{1 f})$ & $1910,1805^{a}$ & $1874,(1814,1785)$ \\
\hline$\left[\mathrm{Mn}(\mathrm{ptbpy})(\mathrm{CO})_{3} \mathrm{Br}\right](2)$ & 2023, 1936, 1914 & \\
\hline$\left[\mathrm{Mn}(\mathrm{ptbpy})-(\mathrm{CO})_{3}(\mathrm{MeCN})\right]^{+}(\mathbf{2 a})$ & 2044,1958 & \\
\hline$\left[\mathrm{Mn}(\mathrm{ptbpy})(\mathrm{CO})_{3}\right]_{2}(\mathbf{2 b})$ & $\begin{array}{l}\text { 1932, } 1880,1868, \\
1847\end{array}$ & \\
\hline$\left[\mathrm{HMn}\left(\mathrm{ptbpy}-\mathrm{H}^{+}\right)(\mathrm{CO})_{3}\right]^{-}(\mathbf{2 c})$ & 1987 & \\
\hline$\left[\mathrm{Mn}(\mathrm{ptbpy})(\mathrm{CO})_{3}\right]^{-}(\mathbf{2 d})$ & $1912,1817,1804^{a}$ & \\
\hline$\left[\mathrm{HMn}(\mathrm{bpy})(\mathrm{CO})_{3}\right]$ & $1989,1892^{[a]}$ & \\
\hline$\left[\mathrm{HMn}(\mathrm{bpy})(\mathrm{CO})_{3}\right]$ & $1991,1892,1888 \mathrm{sh}$ & $1978,1893,1884$ \\
\hline$\left[\mathrm{Mn}(\mathrm{CO})_{3}(\mathrm{bpy})\right]^{-}$ & $1916,1814.5^{[b]}$ & - \\
\hline$\left[\mathrm{Mn}(\mathrm{CO})_{3}(\mathrm{bpy})\right]^{-}$ & 1911,1811 & $1890,(1816,1812)$ \\
\hline
\end{tabular}

[a] THF as solvent, data from ref. ${ }^{24}$; [b] THF as solvent, data from ref. ${ }^{9 a}$

Tables 1 and S1 summarize the experimental and DFT calculated infrared data for all the transient species proposed here, together with those reported for similar Mn complexes in the literature. In dry acetonitrile and before applying any potentials, 1 shows two different sets of three $v_{c o}$, which are both typical of facially coordinated $\left[\mathrm{Mn}(\mathrm{bpy}-\mathrm{R})(\mathrm{CO})_{3} \mathrm{X}\right]$ complexes (Figure S5a). This is a clear indication ${ }^{[20-21]}$ that the axial $\mathrm{Br}^{-}$in 1 is replaced by the solvent even in the dark and at room temperature. Thus, the IR spectra of MeCN solutions of 1 exhibit mixtures of the original $\mathrm{Br}^{-}$containing complex ( $\mathrm{v}_{\mathrm{co}}$ bands at 2026, 1935, 1925sh $\mathrm{cm}^{-1}$ ) and the MeCN-containing cation $1 \mathrm{a}\left(2044,1961 \mathrm{~cm}^{-1}\right)$, in a timedependent ratio due to the proceeding of the solvolysis equilibrium (Figure S5a). The two low-energy $v_{\mathrm{co}}$ bands of 1 overlap with those of $1 \mathrm{a}$. In a typical run, the solvent complex, 1a, was found to be the major species at the beginning of the IRSEC experiments (Figure S5b). Weaker bands at 1613 and $1623 \mathrm{~cm}^{-1}$ are assigned to the plane stretching of the aromatic rings (bpy and $\mathrm{Ph}$ modes are mixed) of 1 and $1 \mathrm{a}$, respectively. When a potential slightly more negative than R1 is applied, both the series of bands corresponding to the starting forms 1 (2026, 1935, 1925(sh), $1613 \mathrm{~cm}^{-1}$ ) and 1a (2044, 1961, $\left.1623 \mathrm{~cm}^{-1}\right)$ progressively disappear, leading to growth of a new species as major reduction product with absorptions at 2021, 1920(br) (CO stretches) and $1607 \mathrm{~cm}^{-1}$ (ligand-based stretch mostly overlapped with those belonging to 1) (Figure 4).

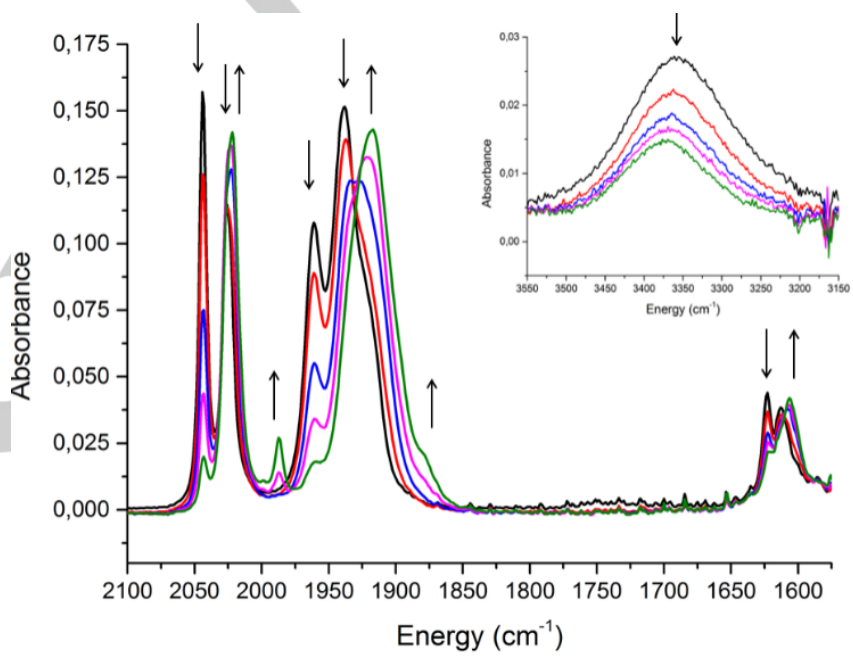

Figure 4. IR-SEC of a $1 \mathrm{mM} \mathrm{MeCN}$ solution of 1 under Ar: reduction at the first peak (R1). The inset shows a concomitant decrease of the $\mathrm{vOH}$

The latter species can be reasonably assigned to a singlydeprotonated neutral species, $\left[\mathrm{Mn}\left(\mathrm{dhbpy}-\mathrm{H}^{+}\right)(\mathrm{CO})_{3}\right] \quad(\mathbf{1 b})$, formed by a reductive deprotonation of the starting $1 \mathrm{a}$ upon $\mathrm{R} 1$. Accordingly to this interpretation, the newly formed bands fit well with the spectroscopic data of $\mathrm{Re}$ and $\mathrm{Mn}$ complexes that contain the 4dhbpy ligand (4,4'-dihydroxy-2,2'-bipyridyl) and in which a reductive deprotonation mechanism was reported. ${ }^{[21,23]}$ In particular, a shift in the high-energy $\mathrm{v}_{\mathrm{CO}}$ from 2019 to 2012 $\mathrm{cm}^{-1}\left(7 \mathrm{~cm}^{-1}\right.$ red shift) was observed in $\left[\operatorname{Re}(4 \mathrm{dhbpy})(\mathrm{CO})_{3} \mathrm{Cl}\right]$ as the starting species transformed into the singly-deprotonated complex $\left[\mathrm{Re}\left(4 \mathrm{dhbpy}-\mathrm{H}^{+}\right)(\mathrm{CO})_{3} \mathrm{Cl}\right]^{-}\left(\right.$Table S1). ${ }^{[23]}$ Similarly, a corresponding $5 \mathrm{~cm}^{-1}$ red shift is experimentally observed passing from $1\left(2026 \mathrm{~cm}^{-1}\right)$ to $\left[\mathrm{Mn}\left(\right.\right.$ pdbpy- $\left.\left.\mathrm{H}^{+}\right)(\mathrm{CO})_{3}\right] \mathbf{1 b}(2021$ $\mathrm{cm}^{-1}$ ). This interpretation is also supported by the decrease of the broad $\mathrm{OH}$ stretching band at around $3359 \mathrm{~cm}^{-1}$ (calculated at $3363 \mathrm{~cm}^{-1}$ ) during the first reduction (Figure 4, inset). The R1 process is also chemically irreversible in IR-SEC, since reoxidation does not restore the initial spectrum (Figure S6). From a structural point of view, DFT calculations suggest that the phenolate group in $\mathbf{1 b}$ may occupy the vacant coordination position (after the release of $\mathrm{MeCN}$ from $1 \mathrm{a}, \mathrm{Mn}-\mathrm{O}=2.052 \AA$ ). 
The interaction between the $\mathrm{Mn}^{\prime}$ center and the negatively charged phenolate unit in the axial position is expected to stabilize the pseudo-octahedral (distorted) structure of $\mathbf{1 b}$, thus accounting for the lack of dimerization upon R1. Furthermore, $\mathrm{Mn}$ retains its original +1 oxidation state in $\mathbf{1 b}$, maintaining a similar electron density on the $\mathrm{Mn}(\mathrm{CO})_{3}$ moiety to that of 1 (as reflected by a very small shift in $\mathrm{v}_{\mathrm{co}}$ ). DFT $\mathrm{v}_{\mathrm{co}}$ predictions of $\mathbf{1}$, $\mathbf{1 a}$ and $\mathbf{1 b}$ well reproduce the experimental data (Table 1).

The two sets of calculated transitions at $1962 / 1951 \mathrm{~cm}^{-1}$ and $1925 / 1916 \mathrm{~cm}^{-1}$ are in good agreement with the broad experimental absorptions at 1961 and $1920 \mathrm{~cm}^{-1}$ for $\mathbf{1 a}$ and $\mathbf{1 b}$, respectively. Finally, it is worth mentioning that the hypothetical assignment of $\mathbf{1 b}$ to the neutral six-coordinate $\left[\mathrm{Mn}\left(\mathrm{dhbpy}-\mathrm{H}^{+}\right)\right.$$(\mathrm{CO})_{3}\left(\mathrm{CH}_{3} \mathrm{CN}\right)$ ] can be ruled out by the absence of any observable band in the region between the $\mathrm{v}_{\mathrm{co}}$ stretches of 1 and $1 \mathrm{a}$, respectively, after $\mathrm{R} 1 .{ }^{[21]}$

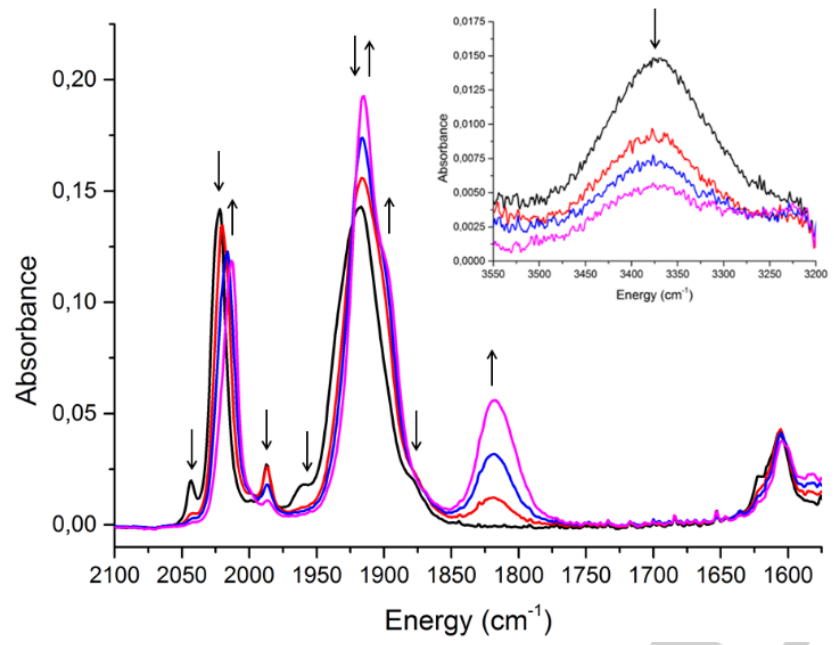

Figure 5. IR-SEC of a $1 \mathrm{mM} \mathrm{MeCN}$ solution of 1 under Ar: reduction at the second peak (R2). The inset shows further decrease of $\mathrm{V}_{\mathrm{OH}}$.

Actually, less intense $v_{c o}$ at 1987 and 1878(sh) $\mathrm{cm}^{-1}$ appear after reduction at R1 in addition to the bands of $\mathbf{1 b}$ (Figure 4). We assign these weak $\mathrm{v}_{\mathrm{co}}$ to the $\mathrm{Mn}$ hydride $\left[\mathrm{HMn}^{\prime}\left(\mathrm{pdbpy}-\mathrm{H}^{+}\right)\right.$$\left.(\mathrm{CO})_{3}\right]^{-}$1c, formed by intramolecular proton transfer from pdbpy to the metal (with a negative charge formally localized on the phenolate). Although rare cases of carbonyl $\mathrm{Mn}$ hydrides have been spectroscopically characterized, similar $\mathrm{v}_{\mathrm{CO}}$ were reported by Riera et al. for the analogous [ $\left.\mathrm{HMn}^{\prime}(\mathrm{bpy})(\mathrm{CO})_{3}\right]$ in THF (1989 and $\left.1892 \mathrm{~cm}^{-1}\right) \cdot{ }^{[24]}$ We were able to reproduce the literature data by performing the IR-SEC of $\left[\mathrm{Mn}(\mathrm{bpy})(\mathrm{CO})_{3} \mathrm{Br}\right]$ in $\mathrm{MeCN}$ with 0.1 $\mathrm{M}$ of phenol (Figure S7). The reduction of the dimer that was initially formed $\left(v_{\mathrm{CO}}\right.$ at $\left.1976,1963 \mathrm{vw}, 1933,1879,1857 \mathrm{~cm}^{-1}\right)$, gave the $\left[\mathrm{Mn}(\mathrm{bpy})(\mathrm{CO})_{3}\right]^{-}$anion $\left(\mathrm{v}_{\mathrm{CO}}\right.$ at 1911 and $\left.1811 \mathrm{~cm}^{-1}\right)$, which is quickly transformed into the hydride species in the presence of $0.1 \mathrm{M}$ phenol ( $\mathrm{v}_{\mathrm{co}}$ at $\left.1991,1892,1888 \mathrm{sh} \mathrm{cm}^{-1}\right)$. In more acidic conditions the production of the dimer is strongly reduced and the hydride is more directly formed (Figure S7b). These data are in good agreement with our experimental and theoretical data on 1c (Table 1).

When the cell potential is stepped more negative to $R 2(\sim-1.5 \mathrm{~V})$, decay of both species $\mathbf{1 b}$ and $\mathbf{1 c}$ produced upon R1 is balanced by simultaneous growth of two different sets of $\mathrm{v}_{\mathrm{CO}}$ stretches, indicating the formation of two new species (Figure 5). The $v_{\mathrm{CO}}$ stretches at 1916 and $1818 \mathrm{~cm}^{-1}$, which are in excellent agreement with several reported doubly-reduced five-coordinate $\mathrm{Mn}$ anions, ${ }^{[8 \mathrm{~b}, 9 \mathrm{a}, 15]}$ can be assigned to the partially deprotonated $\left[\mathrm{Mn}\left(\mathrm{dhbpy}-\mathrm{H}^{+}\right)(\mathrm{CO})_{3}\right]^{2-}$ anion (1d), which still possesses one local $\mathrm{OH}$ group attached to the ligand moiety. Furthermore, concomitantly to $1 \mathrm{~d}$ formation, a $9 \mathrm{~cm}^{-1}$ shift of the IR signal at $2021 \mathrm{~cm}^{-1}$ to lower energy indicates a partial conversion of $1 \mathbf{b}$ into another species, characterized by a growing $v_{\mathrm{CO}}$ stretch at $2012 \mathrm{~cm}^{-1}$ and a poorly resolved shoulder at $1900 \mathrm{~cm}^{-1}$ (Figure 5). The ligand mode at $1607 \mathrm{~cm}^{-1}$ of $\mathbf{1 b}$ is also slightly shifted to $1605 \mathrm{~cm}^{-1}$. These spectroscopic features are consistent with the doubly-deprotonated intermediate $\left[\mathrm{Mn}\left(\mathrm{dhbpy}-2 \mathrm{H}^{+}\right)(\mathrm{CO})_{3}\right]^{-}(\mathbf{1 e})$, derived from further reductive deprotonation of $\mathbf{1 b}$ and structurally similar to the latter. This interpretation is in accordance with further decrease of the $\mathrm{V}_{\mathrm{OH}}$ stretch at $3359 \mathrm{~cm}^{-1}$, which is experimentally seen during R2 in the recorded spectra (Figure 5, inset). Moreover, an analogous red-shift $\left(\sim 10 \mathrm{~cm}^{-1}\right)$ of the high energy $v_{C O}$ stretch was reported for the reductive conversion of the related complex $\left[\operatorname{Re}\left(4 \mathrm{dhbpy}-\mathrm{H}^{+}\right)(\mathrm{CO})_{3} \mathrm{Cl}\right]^{-}$to the doubly-deprotonated $\left[\operatorname{Re}\left(4 \mathrm{dhbpy}-2 \mathrm{H}^{+}\right)(\mathrm{CO})_{3}\right]^{-}\left(\right.$Table S1). ${ }^{[23]}$ The DFT calculated $v_{c o}$ stretches match well with the experimental ones, for either 1d $\left(1892,1832,1808 \mathrm{~cm}^{-1}\right)$ and $1 \mathrm{e}$ $\left(1998,1912,1899 \mathrm{~cm}^{-1}\right)$.

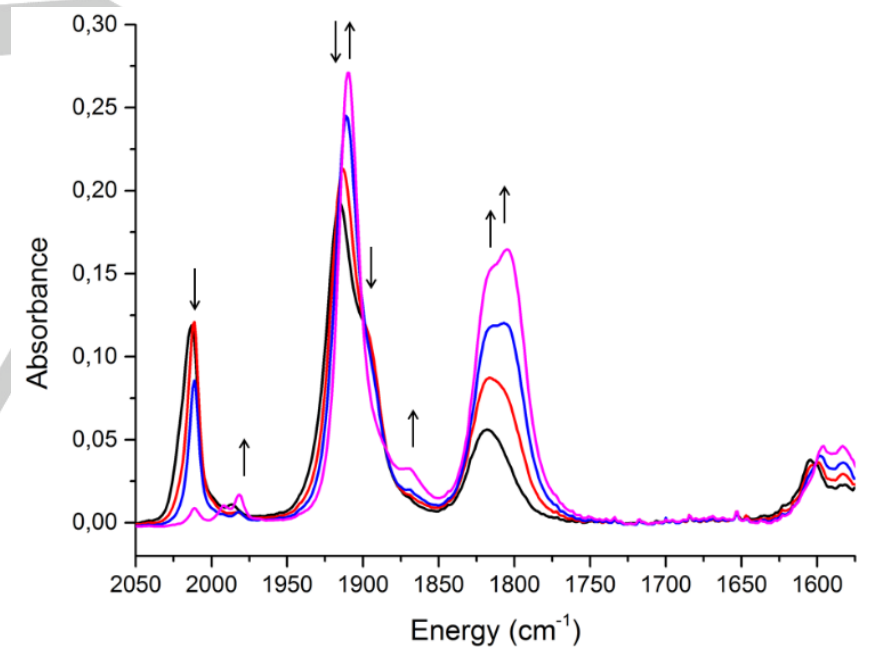

Figure 4. IR-SEC of a $1 \mathrm{mM} M e C N$ solution of 1 under Ar: reduction at the third peak (R3).

The $v_{c O}$ at 2012 and $1900 \mathrm{~cm}^{-1}$ disappear at slightly more negative potentials, while $v_{C O}$ centered at 1910, 1817 and 1805 $\mathrm{cm}^{-1}$ appear (Figure 6). The net result is that the IR spectrum at the end of the reduction shows a very intense sharp $v_{\mathrm{CO}}$ at 1910 $\mathrm{cm}^{-1}$ and a broader one, split into two maxima at 1817 and 1805 $\mathrm{cm}^{-1}$, respectively. These spectral changes likely indicate that the 1d anion coexists with its deprotonated counterpart $\left[\mathrm{Mn}\left(\text { pdbpy }-2 \mathrm{H}^{+}\right)(\mathrm{CO})_{3}\right]^{3-}$ (1f) in solution, resulting from the reduction of $\mathbf{1 e}$. $\mathbf{1 d}$ and $\mathbf{1 f}$ share the same five-coordinate geometry as the $\left[\mathrm{Mn}(\mathrm{bpy}-\mathrm{R})(\mathrm{CO})_{3}\right]^{-}$species, as suggested by the similarity in their IR features (see Table 1). ${ }^{[8 b, 9 a, 15]}$ It should 
be also mentioned that direct interconversion between $\mathbf{1 d}$ and $\mathbf{1 f}$ via acid-base equilibria in solution is non-negligible due to the $\mathrm{pH}$-dependent properties of the pdbpy ligand. For this reason, it is hard to clearly distinguish the differently protonated anionic forms in the experimental IR spectra. ${ }^{[1]}$ These chemical complications, as well as the highly reducing potentials, probably contribute to the appearance of some minor Mn species in the final spectrum, characterized by very weak $v_{\mathrm{CO}}$ bands (e.g. at 1982 and $1869 \mathrm{~cm}^{-1}$, Figure 6).

IR-SEC of 2 in $\mathrm{CH}_{3} \mathrm{CN} / \mathrm{TBAPF}_{6}$. As preliminarily suggested by CV data, an IR-SEC study of 2 confirmed the remarkable differences in the reduction mechanism with respect to $\mathbf{1}$, highlighting the crucial role played by the local proton source. The solvolysis equilibrium in $\mathbf{2}$ is less marked than in 1, so that the IR spectrum of a MeCN solution of 2 shows three main $v_{\mathrm{CO}}$ at 2023,1936 and $1914 \mathrm{~cm}^{-1}$, corresponding to the $\mathrm{Br}$ containing initial form. However, bands at 2044 and $1958 \mathrm{~cm}^{-1}$ (Figure S8) rapidly grow just before the first reduction, suggesting that the cationic $\left[\mathrm{Mn}(\mathrm{ptbpy})(\mathrm{CO})_{3}\left(\mathrm{CH}_{3} \mathrm{CN}\right)\right]^{+}(2 \mathrm{a})$ complex is rapidly generated by a catalytic ETC (electron transfer chain) reaction. ${ }^{[25]}$

Upon the first reduction R1', decrease in the $v_{c o}$ of $2(2023$, 1936, $\left.1914 \mathrm{~cm}^{-1}\right)$ and 2a $\left(2044,1958 \mathrm{~cm}^{-1}\right)$ is balanced by the growth of $\mathrm{v}_{\mathrm{CO}}$ at 1932,1880, 1868 and $1847 \mathrm{~cm}^{-1}$, likely corresponding to the dimer $\left[\mathrm{Mn}(\mathrm{ptbpy})(\mathrm{CO})_{3}\right]_{2}$ (2b) (Figure 7).

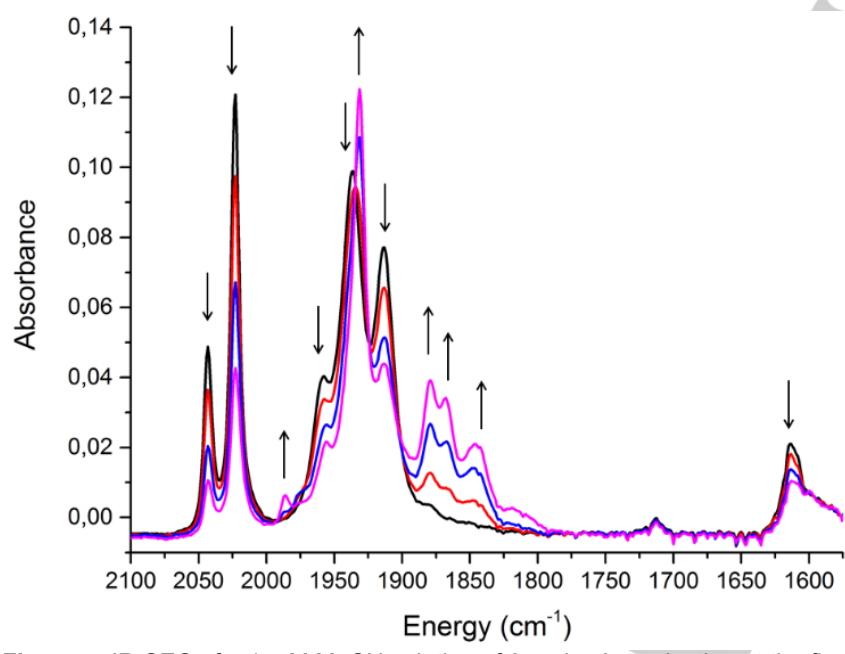

Figure 5. IR-SEC of a $1 \mathrm{mM} \mathrm{MeCN}$ solution of $\mathbf{2}$ under Ar: reduction at the first peak (R1').

This interpretation matches not only with the $\mathrm{CV}$ data of $\mathbf{2}$, but also with the experimental IR-SEC data reported for analogous systems. ${ }^{[9 a, 12]}$ A small peak at $1987 \mathrm{~cm}^{-1}$ also grows during $\mathrm{R} 1$ ', indicating the partial formation of a Mn hydride species ([HMn$\left(\right.$ ptbpy $\left.\left.-\mathrm{H}^{+}\right)(\mathrm{CO})_{3}\right]^{-}, 2 \mathrm{c}$ (or protonated counterparts). Consistently with a less spatial interaction between the intramolecular phenolic groups and the metal atom in 2 , it is apparent that the hydride $\mathbf{2 c}$ is generated in-situ in a considerably smaller amount than the analogue 1c.

At increasingly negative potential values, the $v_{c o}$ of the dimer decrease, while the very intense $v_{\mathrm{CO}}$ at 1912, 1817 and 1804 $\mathrm{cm}^{-1}$ start to increase (Figure 8 ). These spectral changes are consistent with a reductive cleavage of the dimer to generate the five-coordinate $\left[\mathrm{Mn}(\mathrm{ptbpy})(\mathrm{CO})_{3}\right]^{-}(\mathbf{2 d})$ anion. The similarity between the IR spectrum shown in Figure 8 and the one obtained after the IR-SEC experiment on 1 (Figure 6), prompted us to assign the increasing bands at 1912, 1817 and $1804 \mathrm{~cm}^{-1}$ to a mixture of differently protonated anionic species (mostly derived from acid-base processes).

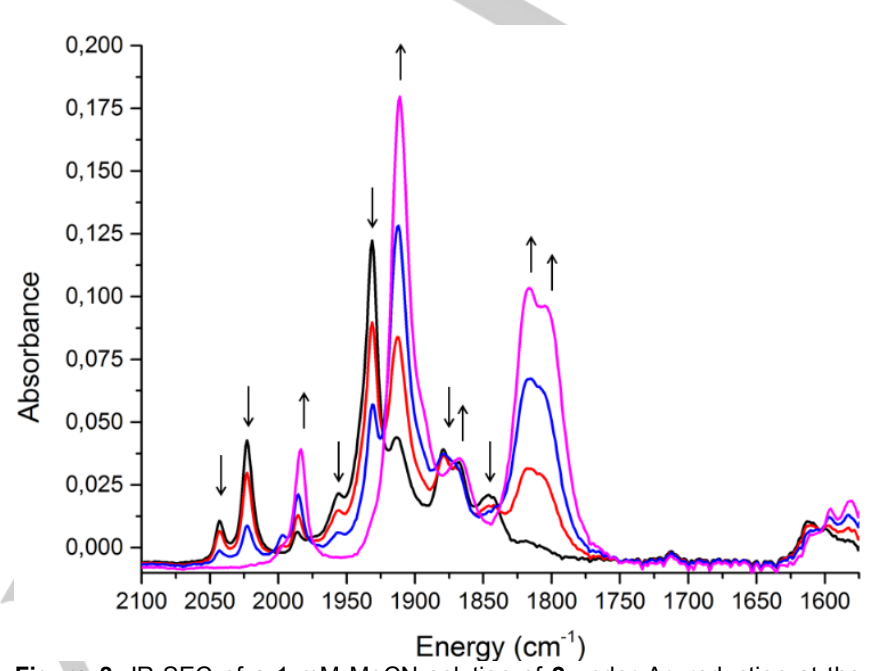

Figure 8. IR-SEC of a $1 \mathrm{mM} \mathrm{MeCN}$ solution of 2 under Ar: reduction at the second peak (R2')

UV-Vis Spectroelectrochemistry (UV-Vis SEC) under Ar. In the OTTLE cell, at open circuit, the UV-Vis spectrum of 1 in MeCN shows a series of absorptions at 382, 283(sh), 273 and $250 \mathrm{~nm}$ (Figures9a), which do not undergo any appreciable changes during the electrochemical reduction $R 1$. This is consistent with the formation of $\mathbf{1 b}$ upon R1, as the theoretical UV-Vis spectra of $\mathbf{1 a}$ and $\mathbf{1 b}$ (Figure S10) resulted to be very similar to each other. Importantly, the absence of any intense absorption at around $800 \mathrm{~nm}$ confirmed the lack of dimerization after R1, as already evidenced by the electrochemical and IRSEC results. ${ }^{[8 a, 9 a]}$ When the applied potential is close to R2 (ca. $-1.5 \mathrm{~V}$ ), a broad absorption at $627 \mathrm{~nm}$ and other minor bands at $375,243 \mathrm{~nm}$ start to grow to the detriment of the maxima at 283 , 273, $250 \mathrm{~nm}$ (Figure S9b), indicating the formation of a fivecoordinate anion, analogous to $\left[\mathrm{Mn}(\mathrm{bpy})(\mathrm{CO})_{3}\right]^{-}$produced upon $2 \mathrm{e}$ reduction of $\left[\mathrm{Mn}(\mathrm{bpy})(\mathrm{CO})_{3} \mathrm{Br}\right]$ in $\mathrm{MeCN}^{\left[{ }^{[a]}\right.}$ At slightly more negative potentials, the band at $243 \mathrm{~nm}$ decreases, with an isosbestic point at $290 \mathrm{~nm}$, while a new, intense band appears at $506 \mathrm{~nm}$ and the maximum at $627 \mathrm{~nm}$ is slightly blue-shifted to $622 \mathrm{~nm}$ (Figure S9c). These spectral changes are in agreement with the formation of a mixture of analogous pentacoordinated Mn species after R3. ${ }^{[8]}$

Proposed reduction mechanisms under Ar. The set of experimental data in $\mathrm{MeCN}$ led us to propose two different reduction routes for 1 (Scheme 1 ) and 2 (Scheme 2). A rational understanding of the reduction pathway for 1 should take into account the solvolysis process which provides an initial mixture of 1 and 1a. Since it seems reasonable to assume that the reduction of 1a occurs more positively than 1 and IR-SEC clearly 
showed that $\mathbf{1 a}$ is thermodynamically favored over $\mathbf{1}$, we will consider R1 simply describing the $1 \mathrm{e}$ reduction of $\mathbf{1 a}$. As evidenced by IR-SEC, chemical complications interfere with the redox process occurring at $R 1$, yielding the neutral $1 \mathrm{~b}$ species as the major product via a reductive deprotonation of 1a (after release of a solvent molecule).
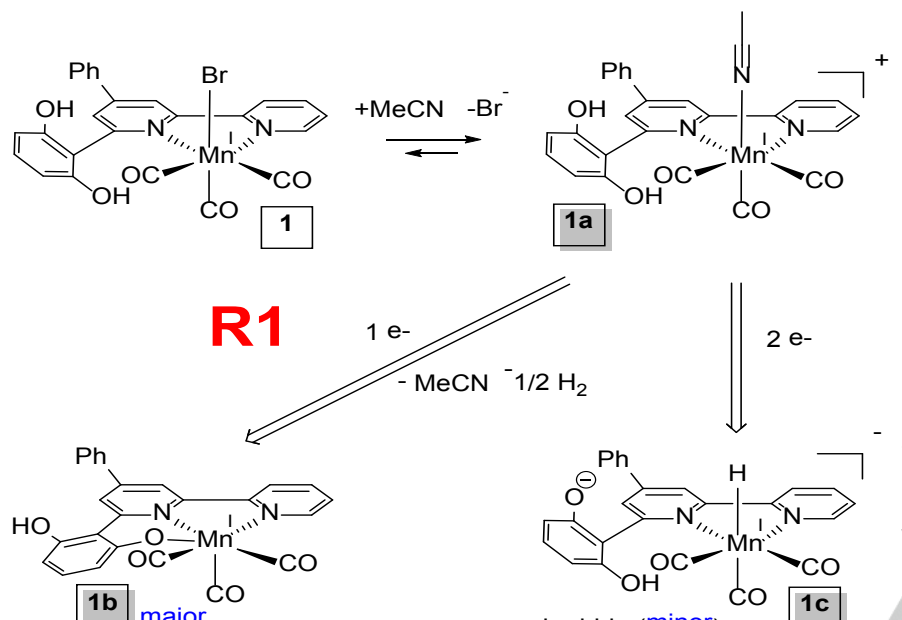

hydride (minor)

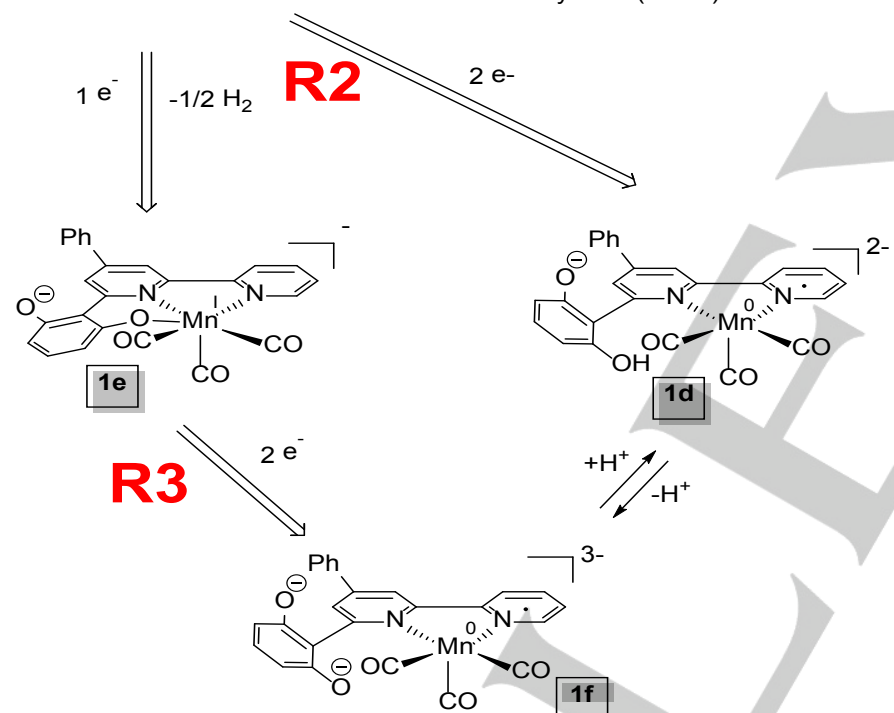

Scheme 1. Electrochemical mechanism for 1 under Ar.

As discussed above, reductive deprotonation is not uncommon in Group VII carbonyl complexes containing pyridinol moieties. ${ }^{[21,23]}$ No experimental evidence of dimerization after R1 was obtained. However, a small amount of the hydride 1c was detected by IR-SEC at this reduction potential. Formally, it should be produced via an overall two electron reduction, but electrolysis (at longer timescale than SEC) apparently consumed only one electron per molecule of 1 . By the way, as suggested by DFT calculations, the reactions of $1 \mathrm{c}$ with the starting complexes $\mathbf{1}$ or $\mathbf{1 a}$ leading to $\mathbf{1 b}$ are thermodynamically spontaneous $\left(\Delta \mathrm{G}=-103.7 \mathrm{~kJ} / \mathrm{mol}\right.$ for $1 \mathrm{c}+\mathbf{1} \rightarrow 2 \mathbf{1 b}+\mathrm{H}_{2}+\mathrm{Br}^{-}$ and $\Delta \mathrm{G}=-110.7 \mathrm{~kJ} / \mathrm{mol}$ for $1 \mathrm{c}+1 \mathrm{a} \rightarrow 2 \mathbf{1 b}+\mathrm{H}_{2}+\mathrm{MeCN}$ ), thus accounting for the overall consumption of one electron per molecule of $\mathbf{1 b}$ produced.

At the onset potential of $\mathbf{R} 2, \mathbf{1} \mathbf{b}$ is reduced into a transient radical species (not experimentally observed), which undergoes two competing chemical processes. Firstly, as an effect of increasing negative charge over the diimine moiety, the axial phenolate coordination to $\mathrm{Mn}$ becomes more labile in the reduced form of $\mathbf{1 b}$, promoting dissociation of the $\mathrm{Mn}-\mathrm{O}$ bond. + Upon R2, the resulting species further reduces to produce the doubly-reduced, singly-deprotonated anion $1 \mathrm{~d}$. In parallel, the aforementioned short-lived radical species may undergo another reductive deprotonation, providing the doubly-deprotonated intermediate 1e. The net result is that, as observed by IR-SEC 1d and 1e coexist at the potential of R2 (Figure 5). The electrochemical conversion of $\mathbf{1 e}$ into $\mathbf{1 f}$ is analogue to the conversion of $\mathbf{1 b}$ into $\mathbf{1 d}$. The proposed mechanism is also in agreement with the voltammetric behavior of 1 at different scan rates (Figure S2).

The electrochemical behavior of $\mathbf{2}$ under $\mathrm{Ar}$ is straightforward (Scheme 2), and similar to other $\left[\mathrm{Mn}\right.$ (diimine) $\left.(\mathrm{CO})_{3} \mathrm{X}\right]$ complexes, where the formation of the dimer $\mathbf{2} \mathbf{b}$ is the only relevant process experimentally observed upon the first $1 \mathrm{e}$ reduction ( $\mathrm{R} 1$ '). The hydride 2c, albeit detected in IR-SEC, is produced only in very small amount, if compared with 1c. Unlike 1, CV and IR-SEC gave no indication of deprotonation during the first reduction of 2. In the subsequent reduction, R2', the reductive cleavage of $\mathbf{2} \mathbf{b}$ produces the pentacoordinated anion $\mathbf{2 d}$ (or a mixture of differently protonated anions).

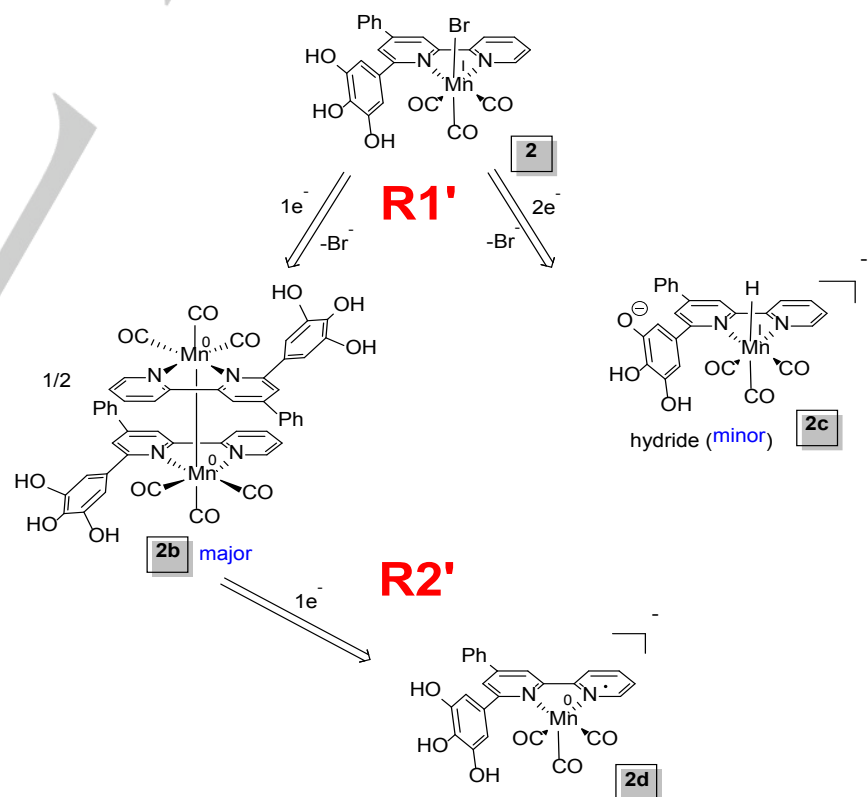

Scheme 2. Electrochemical mechanism for 2 under $\mathrm{Ar}$.

Catalytic behavior under $\mathrm{CO}_{2}$. To investigate the catalytic process, we performed IR-SEC on a MeCN/TBAPF 6 solution of 1 under $\mathrm{CO}_{2}$-saturated conditions. During the first reduction, where no catalytic current in $\mathrm{CV}$ was observed, the recorded spectra are similar to those obtained under $\mathrm{Ar}$, as the 
consumption of the starting species 1 and $1 \mathrm{a}$ gives the catalytically inactive neutral intermediate $\mathbf{1 b}$, with typical $\mathrm{v}_{\mathrm{co}}$ at 2021, $1918 \mathrm{~cm}^{-1}$ and the ligand-based absorption at $1607 \mathrm{~cm}^{-1}$ (Figure S12). Interestingly, the characteristic $v_{\mathrm{CO}}$ of $1 \mathrm{c}$ are not observed at R1 and are replaced by growth of new bands in the $1700-1500 \mathrm{~cm}^{-1}$ region of the FTIR spectra. This seems to suggest that either the $\mathrm{Mn}$ hydride $1 \mathrm{c}$ or its radical precursor may interact with the substrate. Unfortunately this new set of $\mathrm{v}_{\mathrm{cO}}$ cannot be univocally assigned to $\mathrm{CO}_{2}$ reduction products (e.g. free $\mathrm{HCOO}^{-}$) or to a $\mathrm{Mn}-\mathrm{CO}_{2}$ adduct due to partial overlap with the bands of $\mathbf{1 b},{ }^{[15,26]}$ so that we cannot rule out the formation of a new fac-tricarbonyl $\mathrm{Mn}^{\prime}-\mathrm{CO}_{2}$ complex, as found for an analogous $\mathrm{Mn}^{\prime}$ and $\mathrm{Re}^{\prime}$ catalysts. ${ }^{[15,23,26,29]}$ Besides this, the asymmetric $v_{\text {coo }}$ stretches of such adducts (between 1700-1600 $\mathrm{cm}^{-1}$ ) would also completely overlap with those of $\mathrm{HCO}_{3}{ }^{-} / \mathrm{CO}_{3}{ }^{2-}$ ${ }^{[9 b, 27]}$ In agreement with the $\mathrm{CV}$ data, the catalytic $\mathrm{CO}_{2}$ reduction process starts at more negative potentials than $\mathrm{R} 1$, as suggested by an evident decay of the $\mathrm{CO}_{2}$ signal at $2342 \mathrm{~cm}^{-1}$ (asymmetric stretching mode). In the $\mathrm{v}_{\mathrm{CO}}$ region the high-energy band of $\mathbf{1 b}$ is slightly shifted to $2019 \mathrm{~cm}^{-1}$, whereas the broad absorption at $1918 \mathrm{~cm}^{-1}$ is slowly replaced by two different $\mathrm{v}_{\mathrm{CO}}$ at 1921 and $1907 \mathrm{~cm}^{-1}$ (Figure S13). The recorded IR spectra do not change significantly once these three bands are fully grown up, as expected for the proceeding of a typical catalytic run. No bands around $1800 \mathrm{~cm}^{-1}$ related to the anions $1 \mathbf{d}$ or $\mathbf{1 f}$, considered catalytically active for $\mathrm{CO}$ production, were observed (Figure S13). At the same time, the rapid increase of the band at $1607 \mathrm{~cm}^{-1}$, which is partially overlapped with the bpy-based mode of $\mathbf{1 b}$, gives a clear indication of the electrocatalytic formation of free formate. ${ }^{[9 b, 27]}$ This is in agreement with the results of the bulk electrolysis performed on 1 under $\mathrm{CO}_{2}$ in dry MeCN. ${ }^{[17]}$ Moreover, two other bands, increasing at 1684 and $1646 \mathrm{~cm}^{-1}$, can be assigned to free bicarbonate, ${ }^{[9 b, 9 d, 27]}$ and are often related to catalytic $\mathrm{CO}$ production. Finally, as previously observed ${ }^{[28]}$ evolution of gas on the working electrode surface and a small rising peak, caused by $\mathrm{CO}$ adsorbed on $\mathrm{Pt}$, was seen at $2138 \mathrm{~cm}^{-1}$. The band at $1646 \mathrm{~cm}^{-1}$ may result from the overlap with that of the carbonate ion (as an ion pair), since it appears to grow independently of the signal at $1684 \mathrm{~cm}^{-1} \cdot{ }^{[\mathrm{bb}, 29]} \mathrm{At}$ lower $\mathrm{CO}_{2}$ concentrations, the three $\mathrm{v}_{\mathrm{CO}}$ at 2019, 1921 and 1907 $\mathrm{cm}^{-1}$ are isosbestically converted into a mixture of $1 \mathrm{~d}$ and $1 \mathrm{e}$ only after the consumption of approximately $50 \%$ of the starting $\mathrm{CO}_{2}$ (Figure S14)

Analogously to $1, \mathrm{CV}$ of the complex 2 in a $\mathrm{CO}_{2}$ saturated $\mathrm{MeCN}$ solution exhibits an increased peak current upon the second reduction R2' (at $-1.50 \mathrm{~V}$, Figure 3 ), even though the observed electrocatalytic current enhancement is much lower in comparison to $\mathbf{1}$ under the same conditions (Figure 2). Accordingly with the electrochemical data, no catalytic process is observed after the first reduction in IR-SEC in a $\mathrm{CO}_{2}$-saturated $\mathrm{MeCN}$ solution of $\mathbf{2}$ (Figure S15), but the dimer $\mathbf{2} \mathbf{b}$ is quantitatively produced from the starting $\mathbf{2}$ and $\mathbf{2 a}$. However, as previously discussed for 1 , the small $v_{\mathrm{CO}}$ at $1987 \mathrm{~cm}^{-1}$, assigned to the $\mathrm{Mn}$ hydride $\mathbf{2 c}$, is no longer detected during reduction under $\mathrm{CO}_{2}$. As in 1, a catalytic behavior is observed at the foot of the second reduction, showing a growth of bands at 1684, 1646 (free $\mathrm{HCO}_{3}{ }^{-} / \mathrm{CO}_{3}{ }^{2-}$ ) and 1607 (free formate) $\mathrm{cm}^{-1}$ concomitantly to a decrease of the $\mathrm{CO}_{2}$ stretching mode at $2342 \mathrm{~cm}^{-1}$ (Figure S16). Nevertheless, the detection of $\mathbf{2 d}$ even under $\mathrm{CO}_{2-}$ saturated conditions confirms the reduced catalytic activity of 2 in comparison with 1. Furthermore, growth of the IR signal at $1607 \mathrm{~cm}^{-1}$ during catalytic $\mathrm{CO}_{2}$ reduction is less evident than in the case of 1 . This may suggest a slower formation of the hydride species, believed to be responsible for catalytic $\mathrm{CO}_{2}$ conversion into formate, and is consistent with a more difficult intramolecular $\mathrm{H}^{+}$transfer for 2.

Electrolysis under $\mathrm{CO}_{2}$ in the presence of Brønsted acids. The catalytic performances of $\mathbf{1}$ and $\mathbf{2}$ were also investigated in the presence of different Brønsted acids. In particular, water, TFE or phenol $(2.7 \mathrm{M})$ were added to $\mathrm{MeCN}$ solutions $(0.5 \mathrm{mM})$ of 1 and 2. Bulk electrolysis was performed at $-1.50 \mathrm{~V}$ (for $2 \mathrm{~h}$ ) and $-1.70 \mathrm{~V}$ (for $3 \mathrm{~h}$ with water and phenol and for $50 \mathrm{~min}$ with TFE), for 1 and 2 , respectively. Table 2 summarizes the quantitative results obtained during the exhaustive experiments.

Table 2. TON and faradic efficiencies $(\eta)$ from bulk electrolysis (applied potentials $E$ in $V$ vs. SCE) of a $0.1 \mathrm{M} \mathrm{TBAPF}_{6} \mathrm{MeCN}$ solutions of 1 and 2 (0.5 $\mathrm{mM})$ in the presence of different Brønsted acids (2.7 M).

\begin{tabular}{|c|c|c|c|c|c|c|c|c|c|}
\hline \multirow{2}{*}{ Catalyst } & \multirow{2}{*}{$\begin{array}{c}E \\
\text { (V) }\end{array}$} & \multirow{2}{*}{$\begin{array}{l}\text { Time } \\
(\min )\end{array}$} & \multirow{2}{*}{$\begin{array}{l}\text { Acid } \\
(2.7 \mathrm{M})\end{array}$} & \multicolumn{3}{|c|}{ TON } & \multicolumn{3}{|c|}{$(\eta \%)$} \\
\hline & & & & $\mathrm{CO}$ & $\mathrm{HCOO}^{-}$ & $\mathrm{H}_{2}$ & $\mathrm{CO}$ & $\mathrm{HCOO}^{-}$ & $\overline{\mathrm{H}_{2}}$ \\
\hline 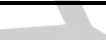 & -1.50 & 120 & $\mathrm{H}_{2} \mathrm{O}$ & 28 & 1.4 & 0.7 & 90 & 4 & 2 \\
\hline \multirow[t]{3}{*}{1} & -1.50 & 120 & TFE & 11 & 9 & 0.8 & 48 & 36 & 3 \\
\hline & -1.50 & 120 & phenol & 4 & 12 & 5.5 & 15 & 39 & 21 \\
\hline & -1.70 & 180 & $\mathrm{H}_{2} \mathrm{O}$ & 7 & 0.5 & 0.2 & 74 & 4 & 2 \\
\hline \multirow[t]{2}{*}{2} & -1.70 & 50 & TFE & 2 & 0.3 & 0.04 & 74 & 10 & 1 \\
\hline & -1.70 & 180 & phenol & 2 & 0.8 & 0.9 & 56 & 15 & 17 \\
\hline
\end{tabular}

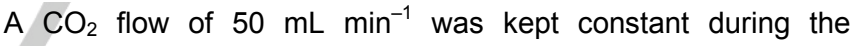
experiments, whereas gaseous and liquid $\mathrm{CO}_{2}$ reduction products were determined by gas (GC) and ion (IC) chromatography, respectively. CVs carried out on solutions of 1 and 2 in the presence of $\mathrm{H}_{2} \mathrm{O}$ show a significant catalytic current enhancement under $\mathrm{CO}_{2}$ (Figure 9a), which is in agreement with previously reported $\mathrm{Mn}$ catalysts. Notably, the catalytic currents observed for 1 at the peak potentials of R2 and R3, in aqueous $\mathrm{MeCN}$ under $\mathrm{CO}_{2}$, are considerably higher than the peak current achieved under an inert atmosphere at the same potentials, indicating that 1 is able to efficiently and selectively reduce $\mathrm{CO}_{2}$, even in the presence of a considerable amount of water (Figure $9 a)$. In this case the wave seems to have reached a plateau, so that we can roughly estimate the catalytic rate constant, $k_{c a t}{ }^{[0]}$ equal to $81 \mathrm{~s}^{-1}$. An analogous selective catalytic mechanism for $\mathrm{CO}_{2}$ reduction is expected also for 2 , being characterized however by a considerably lower catalytic current under $\mathrm{CO}_{2}$ (Figure 9b).

Bulk electrolysis experiments on $\mathrm{CO}_{2}$-saturated aqueous $\mathrm{MeCN}$ solutions well reproduce the $\mathrm{CV}$ data, revealing selective $\mathrm{CO}$ production. In particular, faradaic efficiencies $\eta_{c o}$ of $90 \%$ and $74 \%$ with TON $_{\mathrm{CO}}$ of 28 and 7 were found for $\mathbf{1}$ and $\mathbf{2}$, respectively (Figure $\mathrm{S} 17 \mathrm{a}-\mathrm{b}$ ). Conversely, the competing catalytic processes that yield $\mathrm{HCOO}^{-}$and $\mathrm{H}_{2}$ are almost 
suppressed, providing $\eta_{\mathrm{HCOO}}=4 \%\left(\mathrm{TON}_{\mathrm{HCOO}}\right.$ of 1.4 for 1 and 0.5 for 2) and $\eta_{\mathrm{H} 2}=2 \%\left(\mathrm{TON}_{\mathrm{H} 2}\right.$ of 0.7 for 1 and 0.2 for 2$)$ for both catalysts.
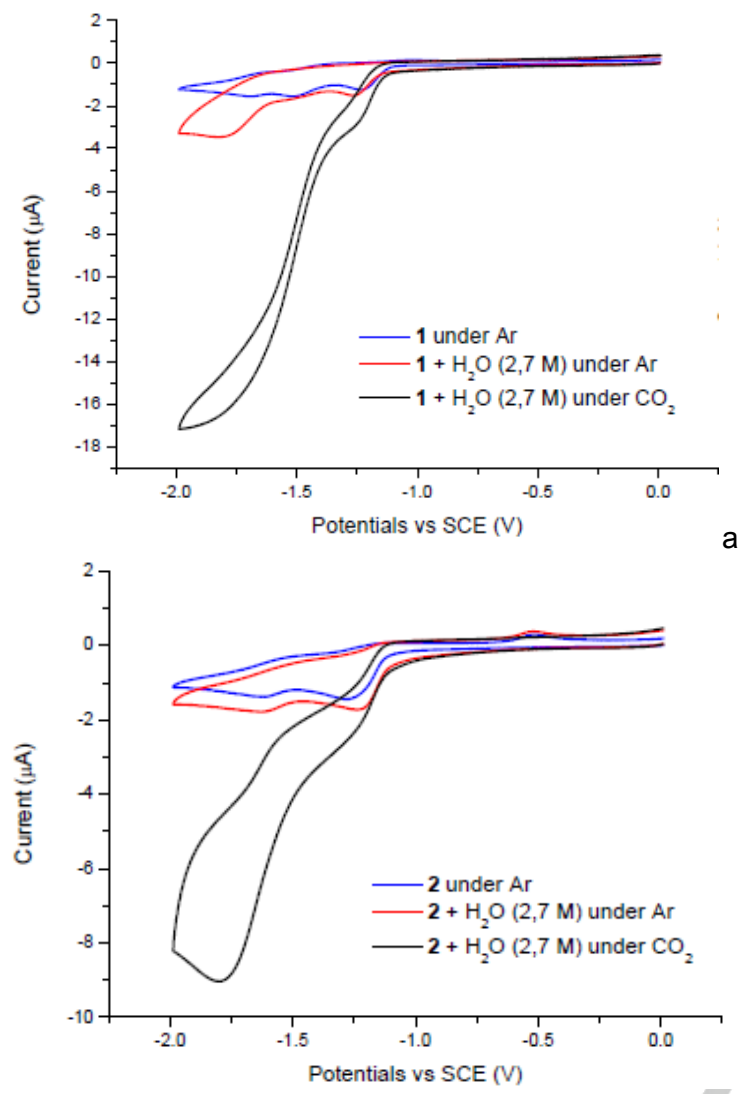

a)

Figure 9. $\mathrm{CVs}$ at $100 \mathrm{mV} \mathrm{s}^{-1}$ of $0.5 \mathrm{mM} \mathrm{MeCN}$ solutions of 1 and 2 under $\mathrm{Ar}$ (blue), under $\mathrm{Ar}$ and with $\mathrm{H}_{2} \mathrm{O} 2.7 \mathrm{M}$ (red) and under $\mathrm{CO}_{2}$ and with $\mathrm{H}_{2} \mathrm{O} 2.7 \mathrm{M}$ (black).

The presence of stronger Brønsted acids like TFE and phenol highlighted important differences in the product distribution of 1 and 2. Unlike catalyst 2, which remains basically selective towards $\mathrm{CO}$ production regardless of the acid employed, 1 exhibits a much more pronounced acid-dependent change in selectivity. In particular, in the presence of TFE, CO is still found as the major product $\left(\eta_{C O}=48 \%\right.$, TON $\left.\mathrm{CO}_{\mathrm{CO}}=11\right)$ (Figure S17c), whereas the catalytic production of $\mathrm{HCOO}^{-}$increases significantly $\left(\eta_{\mathrm{HCOO}}\right.$ $=36 \%$, $\mathrm{TON}_{\mathrm{HCOO}}=9$ ), giving an almost $1: 1 \mathrm{CO} / \mathrm{HCOO}^{-}$ratio. In these conditions, $\mathrm{H}_{2}$ is still produced in negligible quantities $\left(\eta_{\mathrm{H} 2}\right.$ $=3 \%, \mathrm{TON}_{\mathrm{H} 2}=0.8$ ). This trend is amplified upon using an even stronger Brønsted acid like phenol (2.7 M), leading to $\mathrm{HCOO}^{-}$as the major product $\left(\eta_{\mathrm{HCOO}}=39 \%\right.$, $\left.\mathrm{TON}_{\mathrm{HCOO}}=12\right)$ and to $\mathrm{CO}$ in minor quantities $\left(\eta_{\mathrm{CO}}=15 \%, \mathrm{TON}_{\mathrm{CO}}=4\right)$. At the same time, $\mathrm{H}^{+}$ reduction becomes significant $\left(\eta_{\mathrm{H} 2}=21 \% \mathrm{TON}_{\mathrm{H} 2}=5.5\right.$, Figure S18). Under the same experimental conditions, the catalytic selectivity of $\mathbf{2}$ is found to be less sensitive to the strength of the added acid than 1. In particular, the electrocatalytic reduction of $\mathrm{CO}_{2}$ to $\mathrm{CO}$ is still the main process, giving $\eta_{\mathrm{CO}}=74 \%\left(\mathrm{TON}_{\mathrm{CO}}=\right.$ 2, Figure $\mathrm{S} 17 \mathrm{~d})$ and $56 \%\left(\mathrm{TON}_{\mathrm{CO}}=2\right.$, Figure $\left.\mathrm{S} 19\right)$ at $-1.70 \mathrm{~V}$ with $2.7 \mathrm{M}$ TFE and phenol, respectively. $\mathrm{HCOO}^{-}$is formed in minor amounts, with $\eta_{\mathrm{HCOO}}=10 \%\left(\mathrm{TON}_{\mathrm{HCOO}}=0.3\right.$ with TFE $)$ and $15 \%\left(\mathrm{TON}_{\mathrm{HCOO}}=0.8\right.$ with phenol). Finally, bulk electrolysis in $\mathrm{MeCN}+2.7 \mathrm{M}$ TFE also produced traces of molecular hydrogen by using 2 as a catalyst $\left(\eta_{\mathrm{H} 2}=1 \%, \mathrm{TON}_{\mathrm{H} 2}=0.04\right)$, and in higher quantities when phenol is employed as external proton source $\left(\eta_{\mathrm{H} 2}=17 \%\right.$, $\left.\mathrm{TON}_{\mathrm{H} 2}=0.9\right)$.

\section{Conclusions}

In order to shed light on the influence of a ligand-centered proton relay on the $\mathrm{CO}_{2}$ electroreduction catalyzed by tricarbonyl Mn diimine complexes, the electrochemical and spectroscopic features of the complexes $\mathbf{1}$ and $\mathbf{2}$ were systematically investigated under inert atmosphere as well as under $\mathrm{CO}_{2}$. In particular, the results here presented highlight that how little modification in the position of the bpy-localized phenolic groups (in ortho for $\mathbf{1}$ and in meta/para for 2) is able to produce substantial differences in the reductive mechanism under Ar, even inducing a different reactivity towards $\mathrm{CO}_{2}$. Moreover, the selectivity dependence for the electrocatalytic $\mathrm{CO}_{2}$ reduction process upon the strength of the external proton source was investigated in the presence of three different added acids $\left(\mathrm{H}_{2} \mathrm{O}\right.$, TFE, phenol).

Taken together, CV and UV-Vis/IR-SEC data gave evidence of different electrochemical mechanisms for 1 and 2 under Ar. A fast $\mathrm{Br}^{-}$dissociation of $\mathbf{1}$ at zero applied potential produces the acetonitrile complex 1a as the main starting species in solution, whose $1 \mathrm{e}$ reduction does not lead to dimer formation but rather occurs via a reductive deprotonation process. As a result, the neutral intermediate $\mathbf{1 b}$ is proposed as the main species formed after R1, in agreement with the experimental and DFT results. Furthermore, spectroscopic evidence of small amounts of a Mn hydride (1c) is found after the first reduction, being related to the $\mathrm{OH}$ proximity to the $\mathrm{Mn}$ center. No traces of such hydride species are detected under $\mathrm{CO}_{2}$ atmosphere. IR-SEC under $\mathrm{CO}_{2}$ in dry MeCN qualitatively well reproduces the quantitative loss of selectivity highlighted during bulk electrolysis, providing a mixture of $\mathrm{CO}$ and $\mathrm{HCOO}^{-[17]}$ Notably, the well-known protonindependent mechanism of $\mathrm{CO}_{2}$ disproportionation to $\mathrm{CO}$ and $\mathrm{CO}_{3}{ }^{2-}$ cannot be ruled out under these conditions, as carbonate and bicarbonate anions are spectroscopically observed.

On the other hand, the electrochemical reduction of $\mathbf{2}$ under $\mathrm{Ar}$ follows the general scheme commonly reported for other $\left[\mathrm{Mn}\left(\mathrm{bpy}-\mathrm{R}_{2}\right)(\mathrm{CO})_{3} \mathrm{Br}\right]$ catalysts, indicating that dimerization occurs upon R1'. Only traces of another Mn hydride species (2c) are detected after $\mathrm{R} 1^{\prime}$ in the absence of $\mathrm{CO}_{2}$, but not under $\mathrm{CO}_{2}-$ saturated conditions. Moreover, IR-SEC of $\mathbf{2}$ under $\mathrm{CO}_{2}$ confirmed a non-selective $\mathrm{CO}_{2}$ reduction process in anhydrous $\mathrm{MeCN}$, as well as a reduced electrocatalytic activity in comparison with 1. Since pdbpy and ptbpy display similar bulkiness, the deviation between the electrochemical behavior of $\mathbf{1}$ and $\mathbf{2}$ are consistent with the differences in the proximity of the local proton source from the metal site and in the acidity of the ligand moiety.

Finally, controlled-potential electrolysis with different acids confirms the existence of competing electrocatalytic pathways, 
leading to $\mathrm{CO}_{2}$ conversion to $\mathrm{CO}$ and $\mathrm{HCOO}^{-}$, in a ratio which is highly dependent on the acidity of the solution. Whereas the five-coordinate anions (e.g. 1d, 1f, 2d) are likely responsible for the catalytic $\mathrm{CO}$ production, the $\mathrm{HCOO}^{-}$formation is supposed to be catalyzed by the transient $\mathrm{Mn}$ hydride species (1c, 2c). Notably, addition of water $(2.7 \mathrm{M})$ leads to selective $\mathrm{CO}_{2}$ reduction to $\mathrm{CO}$ by both 1 and 2 , but side $\mathrm{HCOO}^{-}$and $\mathrm{H}_{2}$ productions become more prominent as the strength of the Brønsted acid increases. Accordingly to these experimental data acids stronger than water are able to give a fast reprotonation of the ligand-centered phenolate groups, favoring the in-situ formation of transient hydride species. Going from added water to phenol, the $\mathrm{CO}: \mathrm{HCOO}^{-}$ratio can be tuned from ca. $23: 1$ to $1: 3$ with 1 as catalyst. In the case of 2 , such trend is much less evident than for $\mathbf{1}$ and this may be explained by a slower intramolecular proton transfer to form the catalytically active hydride. We believe that these findings contribute to a better understanding of the factors that control the selectivity of a promising class of earth-abundant transition metal catalysts.

\section{Experimental Section}

\section{General considerations}

NMR spectra were recorded on a JEOL EX 400 spectrometer $\left({ }^{1} \mathrm{H}\right.$ operating frequency $400 \mathrm{MHz}$ ) at $298 \mathrm{~K} .{ }^{1} \mathrm{H}$ and ${ }^{13} \mathrm{C}$ chemical shifts are reported relative to TMS $(\delta=0)$ and referenced against solvent residual peaks. UV-Vis spectra were recorded in the $190-1100 \mathrm{~nm}$ range on an Agilent 8453 spectrophotometer. Infrared spectra were recorded in the $4000-1000 \mathrm{~cm}^{-1}$ range (with a resolution $2 \mathrm{~cm}^{-1}$ ) on a Nicolet iS50 FT-IR spectrometer equipped with a $\mathrm{KBr}$ beam splitter and an MCT/A detector. The microanalysis samples were dried under vacuum to constant weight $\left(20^{\circ} \mathrm{C}, \mathrm{ca} .0 .1 \mathrm{Torr}\right)$. Elemental analyses $(\mathrm{C}, \mathrm{H}, \mathrm{N})$ were performed on a Fisons Instruments 1108 CHNS-O Elemental Analyzer. Tetrabutylammonium hexafluorophosphate $\left(\mathrm{TBAPF}_{6}\right.$, Sigma-Aldrich, 98\%) was recrystallized twice from ethanol and dried before use. All reagents were purchased from Sigma-Aldrich and used as received. Solvents were freshly distilled and purged with argon before use. All Mn complexes under study were carefully protected from light during use. Syntheses of the precursor (E)-picolinoyl-phenyl-ethene (a) and $\mathbf{1}$ have previously been reported. ${ }^{[17]}$

Synthesis of 1-(2-oxo-2-(3,4,5-trimethoxyphenyl)ethyl)pyridinium iodide (b): $20 \mathrm{mmol}$ of $3^{\prime}, 4^{\prime}, 5^{\prime}$-trimethoxyacetophenone and $24 \mathrm{mmol}$ of iodine were refluxed for 3 hours in $50 \mathrm{ml}$ of pyridine. The reaction mixture was cooled to $0^{\circ} \mathrm{C}$ and the yellow product was precipitated, filtered and washed with cold pyridine (yield $80 \%$ ). ${ }^{[31]}{ }^{1} \mathrm{H}-\mathrm{NMR}$ [ $400 \mathrm{MHz},\left(\mathrm{CD}_{3}\right)_{2} \mathrm{CO}$ ]: $\delta / p p m=9.36(\mathrm{~d}, J=5.8 \mathrm{~Hz}, 2 \mathrm{H}), 8.89$ (t, $J=7.9 \mathrm{~Hz}, 1 \mathrm{H}), 8.40$ (t, $J=7.0$ $\mathrm{Hz}, 2 \mathrm{H}), 7.50(\mathrm{~s}, 2 \mathrm{H}), 7.07(\mathrm{~s}, 2 \mathrm{H}), 3.96(\mathrm{~s}, 6 \mathrm{H}), 3.85(\mathrm{~s}, 3 \mathrm{H})$.

Synthesis of 4-phenyl-6-(3,4,5-trimethoxyphenyl)-2,2'-bipyridine (c): $2.8 \mathrm{mmol}$ of (a) and an equivalent amount of (b) were added to a flask with an excess of ammonium acetate $(28 \mathrm{mmol})$ and $20 \mathrm{ml}$ of methanol. The mixture was purged with $\mathrm{Ar}$ for ten minutes and was then heated to reflux for 6 hours. The solution was dried on vacuum and the solid was dissolved in $30 \mathrm{ml}$ of ethyl acetate. The organic phase was washed three times using an aqueous solution of $\mathrm{NaHCO}_{3}(10 \%)$ and then dried using anhydrous $\mathrm{MgSO}_{4}$. The solid collected after removal of the solvent was purified on a silica gel column (petroleum ether/ethyl acetate 7:1; yield: $40 \%) \cdot{ }^{[32]}{ }^{1} \mathrm{H}-\mathrm{NMR}\left(400 \mathrm{MHz},\left(\mathrm{CD}_{3}\right)_{2} \mathrm{CO}\right): \delta / \mathrm{ppm}=8.73-8.67(\mathrm{~m}, 2 \mathrm{H}), 8.42$ (s, 1H), 8.26 (d, J= $7.3 \mathrm{~Hz}, 2 \mathrm{H}), 7.98$ (t, $J=7.9 \mathrm{~Hz}, 1 \mathrm{H}), 7.86(\mathrm{~s}, 1 \mathrm{H})$, $7.53(\mathrm{t}, J=7.7 \mathrm{~Hz}, 2 \mathrm{H}), 7.47-7.41(\mathrm{~m}, 2 \mathrm{H}), 6.41(\mathrm{~s}, 2 \mathrm{H}), 3.90(\mathrm{~s}, 3 \mathrm{H})$, $3.78(\mathrm{~s}, 6 \mathrm{H})$.

Synthesis of 4-phenyl-6-(3,4,5-trihydroxyphenyl)-2,2'-bipyridine (ptbpy): $0.9 \mathrm{mmol}$ of (c) was added to a solution of $\mathrm{HBr}(33 \%)$ in acetic acid and heated to reflux for 72 hours. The mixture was then cooled to room temperature and neutralized using an aqueous solution of $\mathrm{NaOH}$. The green precipitate was filtered and washed with water and chloroform (yield 93\%). ${ }^{1} \mathrm{H}-\mathrm{NMR}\left(400 \mathrm{MHz}, \mathrm{d}_{6}-\mathrm{DMSO}\right): \delta / \mathrm{ppm}=9.14(\mathrm{~s}, 2 \mathrm{H}), 8.73(\mathrm{~d}$, $J=4.7 \mathrm{~Hz}, 1 \mathrm{H}), 8.58-8.56(\mathrm{~m}, 2 \mathrm{H}), 8.48(\mathrm{~s}, 1 \mathrm{H}), 8.03\left(\mathrm{td},{ }^{1} J=7.9 \mathrm{~Hz},{ }^{2} J\right.$ $=1.4 \mathrm{~Hz}, 1 \mathrm{H}), 7.98(\mathrm{~s}, 1 \mathrm{H}), 7.92(\mathrm{~d}, 7.3 \mathrm{~Hz}, 2 \mathrm{H}), 7.58(\mathrm{t}, J=7.6 \mathrm{~Hz}, 2 \mathrm{H})$, 7.53-7.49 (m, 2H), $7.31(\mathrm{~s}, 2 \mathrm{H}) .{ }^{13} \mathrm{C}-\mathrm{NMR}\left(400 \mathrm{MHz}, \mathrm{d}_{6}-\mathrm{DMSO}\right): \delta / \mathrm{ppm}=$ $156.97,155.59,155.44,149.50,149.39,146.39,138.05,137.54,135.15$ $129.47,128.99,127.16,124.55,120.84,117.04,115.63,106.20 . M S$ $\left(\mathrm{ESI}^{+}\right): \mathrm{m} / \mathrm{z}=357.28[\mathrm{M}-\mathrm{H}]^{+}$

Synthesis of $\left[\mathrm{Mn}(\mathrm{ptbpy})(\mathrm{CO})_{3} \mathrm{Br}\right]$ (2): $\mathrm{Mn}(\mathrm{CO})_{5} \mathrm{Br}$ (1 eq) and ptbpy (1.01 eq) were refluxed for 4 hours in diethyl ether under stiring. The reaction mixture was then cooled to room temperature and the orange product was filtered and washed once with diethyl ether (yield $82 \%$ ). ${ }^{1} \mathrm{H}$ NMR $\left(400 \mathrm{MHz},\left(\mathrm{CD}_{3}\right)_{2} \mathrm{CO}\right): \delta / \mathrm{ppm}=9.31(\mathrm{~d}, J=4.7 \mathrm{~Hz}, 1 \mathrm{H}), 8.83-8.79$ (m, 2H), 8.40-8.14 (m, 3H), $8.08(\mathrm{~d}, J=6.2 \mathrm{~Hz}, 2 \mathrm{H}), 7.90(\mathrm{~s}, 1 \mathrm{H}), 7.76-$ $7.71(\mathrm{~m}, 2 \mathrm{H}), 7.58(\mathrm{~m}, 3 \mathrm{H}), 6.75(\mathrm{~s}, 2 \mathrm{H}) .{ }^{13} \mathrm{C}-\mathrm{NMR}\left(400 \mathrm{MHz},\left(\mathrm{CD}_{3}\right)_{2} \mathrm{CO}\right)$ $\delta / \mathrm{ppm}=166.81,158.66,157.56,153.96,150.73,146.69,139.45,136.91$, $135.65,135.00,131.14,130.20,128.43,126.73,125.37,124.71,119.56$, 109.87, 109.78. IR (ATR): 3499, 3306, 2032, 1963, $1912 \mathrm{~cm}^{-1} . \mathrm{MS}$ $\left(\mathrm{ESI}^{+}\right): m / z=573.08,575.02[\mathrm{M}-\mathrm{H}]^{+}$.

\section{Electrochemistry}

All the solvents used for electrochemical experiments were freshly distilled. Cyclic voltammetry experiments were performed using a Metrohm Autolab $302 \mathrm{~N}$ potentiostat. $0.5-1.0 \mathrm{mM}$ solutions of the compounds were used in $\mathrm{MeCN}$, with tetrabutylammonium hexafluorophosphate $\left(\mathrm{TBAPF}_{6}\right)$ as the supporting electrolyte $(0.1 \mathrm{M})$. A single-compartment cell, with a glassy carbon (GC) working electrode $(\varnothing$ $=1 \mathrm{~mm}$ ) was employed, while a Pt counter electrode and a SCE $(\mathrm{KCl}$ $3 \mathrm{M})$ reference electrode were also used. In our experimental conditions, the reference ferrocene/ferrocinium $\left(\mathrm{Fc} / \mathrm{Fc}^{+}\right)$redox is at $\mathrm{E}_{1 / 2}=0.39 \mathrm{~V}$ $\left(\Delta \mathrm{E}_{\mathrm{p}}=65 \mathrm{mV}\right)$. The Ar- and $\mathrm{CO}_{2}$-saturated conditions were achieved by purging gases for 5 minutes before each potential sweep.

\section{Spectroelectrochemistry}

IR-SEC experiments were performed using the optically transparent thinlayer electrode (OTTLE) cell, equipped with a Pt minigrid working and auxiliary electrodes, an $\mathrm{Ag}$ microwire pseudo reference electrode and a $\mathrm{CaF}_{2}$ window. ${ }^{[33]}$ IR spectra were recorded on a Nicolet iS50 FT-IR spectrometer. UV-Vis spectroelectrochemistry was performed using the OTTLE cell equipped with quartz optical windows and spectra were measured with diode-array spectrometer Agilent 8453. The course of spectroelectrochemical experiments was controlled and monitored using a PA4 potentiostat and recorder (Laboratory Devices, Prague, Czech Republic). TBAPF $_{6}$ was used as the supporting electrolyte during the experiments.

\section{Controlled-potential electrolysis}

A double compartment $\mathrm{H}$-type cell was used with a Pt wire as the counter electrode in a bridge separated from the cathodic compartment by a glass frit. A glassy carbon rod was used as the working electrode along with an aqueous SCE reference electrode. CPE experiments were 
performed in acetonitrile with $0.1 \mathrm{M} \mathrm{TBAPF}_{6}$ as the supporting electrolyte and $0.5 \mathrm{mM}$ of the catalysts 1 and 2 at $-1.5 \mathrm{~V}$ and $-1.7 \mathrm{~V}$ vs. SCE, respectively. The acids $\mathrm{H}_{2} \mathrm{O}$, TFE and phenol were added to the solution in equimolar quantity $(2.7 \mathrm{M})$. A controlled flow of $\mathrm{CO}_{2}\left(50 \mathrm{~mL} \mathrm{~min}{ }^{-1}\right)$ measured just before arrival into the cell, was maintained during the $\mathrm{CPE}$ measurements by means of a Smart Trak 100 (Sierra) flow controller. All the electrochemical cells were airtight and equipped with a bubbler that maintained the inner atmosphere but avoided gas overpressure.

\section{Quantitative analysis of $\mathrm{CO}_{2}$ reduction products}

$\mathrm{CO}$ and $\mathrm{H}_{2}$ were detected and quantified using an Agilent 490 Micro GC gas chromatograph equipped with a Molsieve $5 \AA$ column, which was kept at $90^{\circ} \mathrm{C}$ and a pressure of $200 \mathrm{kPa}$, and a thermal conductivity detector. The carrier gas was Ar. The gas inside the measurement cell was sampled for 90 s every five minutes and fill the Micro GC $10 \mu \mathrm{L}$ sample loop, and eventually $500 \mathrm{~nL}$ were injected into the column for the analyses. It was possible to determine the amounts of $\mathrm{CO}$ and $\mathrm{H}_{2}$ produced during the experiment from the concentrations of $\mathrm{CO}$ and $\mathrm{H}_{2}$ in the gas samples and knowledge of the gas flow and the cell volume. We used $\mathrm{Ar}, \mathrm{He}, \mathrm{N}_{2}, \mathrm{O}_{2}, \mathrm{CO}_{2}$ and $\mathrm{CO}$ pure gases (>99.9995\%), from Sapio, for the operation and calibration of the flow controller and $\mathrm{GC}$ apparatus, while $\mathrm{H}_{2}$ was produced using a Claind HyGen hydrogen generator. The detection limits for $\mathrm{CO}$ and $\mathrm{H}_{2}$ were 20 ppmv and 0.5 ppmv respectively. Formic acid production was evaluated using ion chromatography; specifically, a Dionex DX 500 instrument equipped with a Dionex IonPac $\circledast$ AS9-HC column $(200 \mathrm{~mm} \times 4 \mathrm{~mm}$ i.d.), GP40 pump (Dionex), an electrochemical detector ED40 (Dionex) and an Anion SelfRegenerating Suppressor-Ultra (ARSR@-ULTRA, 4-mm, Dionex). Elution was performed in isocratic conditions with an aqueous solution of $\mathrm{K}_{2} \mathrm{CO}_{3}$ $9.010^{-3} \mathrm{M}$ at $0.70 \mathrm{~mL} \mathrm{~min}^{-1}$ flow rate. We observed a retention time of $6.23 \mathrm{~min}$ for the formate anion in these conditions. The $\mathrm{TBAPF}_{6}$ matrix had to be removed for the analysis. Therefore, the samples were filtered and brought to $25.0 \mathrm{~mL}$ in volumetric flasks after basification with ammonia. We then injected $2.00 \mathrm{~mL}$ of each sample into a disposable SPE column (containing BAKERBOND spe ${ }^{\mathrm{TM}}$ Quaternary Amine $(\mathrm{N}+)$ and Carlo Erba Amberlite ${ }^{\circledR} \mathrm{CG}-120$, previously conditioned with $\mathrm{HCl} 0.01$ $\mathrm{M})$ and eluted with $8.00 \mathrm{~mL}$ of $\mathrm{HCl} 0.010 \mathrm{M}$. The resulting solutions were brought to $\mathrm{pH}=12$ using $\mathrm{NaOH} 2 \mathrm{M}$ and analyzed by means of ion chromatography.

\section{Computational Details}

DFT calculations were performed using Gaussian 09 Rev. D. $01,{ }^{[34]}$ including the solvent effect by the conductor-like polarizable continuum model $(\mathrm{CPCM})^{[35]}$ with acetonitrile as solvent. Geometry optimizations were carried out without any constraints using the B3LYP functional, ${ }^{[36]}$ the optimized def2-TZVP basis set for $\mathrm{Mn}$ and $\mathrm{Br}$ and the def2-SVP basis set ${ }^{[37]}$ for all other atoms. The D3 version of Grimme's dispersion method was applied adopting the Becke-Johnson damping scheme. ${ }^{[38]}$ Gibbs Free Energies were determined by thermal corrections for entropy and enthalpy at $298 \mathrm{~K}$ to the electronic energies. In these calculations, the computed harmonic frequencies were scaled by 0.952 to account for anharmonicity. For radical anions, unrestricted Kohn-Sham formalism (UKS) was adopted. The nature of all stationary points were confirmed by normal-mode analysis (no imaginary frequencies were found).

\section{Acknowledgements}

Financial support from project PHOTORECARB (Progetti di Ateneo/CSP 2012, Call 03, Università di Torino \& Compagnia
Sanpaolo) is gratefully acknowledged. J.F. thanks the Grant Agency of the Czech Republic (grant 14-05180S) for support.

Keywords: carbon dioxide $\cdot$ manganese $\cdot$ electrochemistry $•$ DFT calculations $\cdot$ electrocatalysis

[1] a) J. Qiao, Y. Liu, F. Hong, J. Zhang, Chem. Soc. Rev. 2014, 43, 631 675 ; b) J. Ronge, T. Bosserez, D. Martel, C. Nervi, L. Boarino, F. Taulelle, G. Decher, S. Bordiga, J. A. Martens, Chem. Soc. Rev. 2014 43, 7963-7981.

[2] a) C. Costentin, S. Drouet, M. Robert, J. M. Saveant, Science 2012 338, 90-94; b) C. Costentin, G. Passard, M. Robert, J. M. Saveant Proc. Natl. Acad. Sci 2014, 111, 14990-14994; c) C. Costentin, M. Robert, J.-M. Savéant, A. Tatin, Proc. Natl. Acad. Sci. 2015, 112 6882-6886.

[3] a) I. Wender, Fuel Process. Technol. 1996, 48, 189-297; b) M. Dry, E. Catal. Today 2002, 71, 227-241.

[4] C. Rice, S. Ha, R. I. Masel, P. Waszczuk, A. Wieckowski, T. Barnard, J. Power Sources 2002, 111, 83-89.

[5] A. S. Agarwal, Y. Zhai, D. Hill, N. Sridhar, ChemSusChem 2011, 4, 1301-1310.

[6] a) J. Hawecker, J.-M. Lehn, R. Ziessel, J. Chem. Soc. Chem. Commun 1984, 984, 328; b) J. W. Raebiger, J. W. Turner, B. C. Noll, C. J. Curtis, A. Miedaner, B. Cox, D. L. Dubois, N. Renewable, C. B. V, N. Dame, et al., Organometallics 2006, 25, 3345-3351; c) Z. Chen, C. Chen, D. R. Weinberg, P. Kang, J. J. Concepcion, D. P. Harrison, M. S. Brookhart, T. J. Meyer, Chem. Commun. 2011, 47, 12607; d) J. D. Froehlich, C. P. Kubiak, J. Am. Chem. Soc. 2015, 137, 3565-3573.

[7] a) C. M. Bolinger, B. P. Sullivan, D. Conrad, J. A. Gilbert, N. Story, T. J. Meyer, J. Chem. Soc. Commun. 1985, 796-797; b) H. Ishida, H Tanaka, K. Tanaka, T. Tanaka, J. Chem. Soc. Chem. Commun. 1987, 131; c) C. Arana, S. Yan, M. Keshavarz-K., K. T. Potts, H. D. Abruna Inorg. Chem. 1992, 31, 3680-3682; d) A. Taheri, E. J. Thompson, J. C Fettinger, L. A. Berben, ACS Catal. 2015, 5, 7140-7151; e) L. Chen, Z. Guo, X. G. Wei, C. Gallenkamp, J. Bonin, E. Anxolabéhère-Mallart, K C. Lau, T. C. Lau, M. Robert, J. Am. Chem. Soc. 2015, 137, 1091810921; f) P. Kang, C. Cheng, Z. Chen, C. K. Schauer, T. J. Meyer, M. Brookhart, J. Am. Chem. Soc. 2012, 134, 5500-5503; g) P. Kang, S. Zhang, T. J. Meyer, M. Brookhart, Angew. Chem. Int. Ed. 2014, 53 8709-8713.

[8] a) M. Bourrez, F. Molton, S. Chardon-Noblat, A. Deronzier, Angew. Chem. Int. Ed. 2011, 50, 9903-9906; b) J. M. Smieja, M. D. Sampson K. A. Grice, E. E. Benson, J. D. Froehlich, C. P. Kubiak, Inorg. Chem. 2013, 52, 2484-2491; c) F. Franco, C. Cometto, C. Garino, C. Minero F. Sordello, C. Nervi, R. Gobetto, Eur. J. Inorg. Chem. 2015, 2015 296-304; d) F. Franco, C. Cometto, F. Sordello, C. Minero, L. Nencini, J. Fiedler, R. Gobetto, C. Nervi, ChemElectroChem 2015, 2, 1372 1379; e) M. D. Sampson, C. P. Kubiak, J. Am. Chem. Soc. 2016, 138 1386-1393.

[9] a) F. Hartl, B. D. Rossenaar, G. J. Stor, D. J. Stufkens, Recl. des Trav. Chim. des Pays-Bas 2010, 114, 565-570; b) F. P. A. Johnson, M. W George, F. Hartl, J. J. Turner, Organometallics 1996, 15, 3374-3387; c) C. W. Machan, M. D. Sampson, S. A. Chabolla, T. Dang, C. P. Kubiak, Organometallics 2014, 33, 4550-4559; d) Q. Zeng, J. Tory, F. Hartl, Organometallics 2014, 33, 5002-5008.

[10] E. E. Benson, M. D. Sampson, K. A. Grice, J. M. Smieja, J. D. Froehlich, D. Friebel, J. A. Keith, E. A. Carter, A. Nilsson, C. P. Kubiak, Angew. Chem. Int. Ed. 2013, 52, 4841-4844.

[11] M. Bourrez, M. Orio, F. Molton, H. Vezin, C. Duboc, A. Deronzier, S Chardon-Noblat, Angew. Chem. Int. Ed. 2014, 53, 240-243.

[12] D. C. Grills, J. Farrington, B. H. Layne, S. V. Lymar, B. A. Mello, J. M. Preses, J. F. Wishart, J. Am. Chem. Soc. 2014, 136, 5563-5566.

[13] a) J. a. Keith, K. a. Grice, C. P. Kubiak, E. a. Carter, J. Am. Chem. Soc 
2013, 135, 15823-15829; b) C. Riplinger, M. D. Sampson, A. M. Ritzmann, C. P. Kubiak, E. A. Carter, J. Am. Chem. Soc. 2014, 136 16285-16298; c) C. Riplinger, E. A. Carter, ACS Catal. 2015, 5, 900 908

[14] E. E. Benson, C. P. Kubiak, Chem. Commun. 2012, 48, 7374-6.

[15] M. D. Sampson, A. D. Nguyen, K. A. Grice, C. E. Moore, A. L. Rheingold, C. P. Kubiak, J. Am. Chem. Soc. 2015, 137, 3718

[16] We assume that protons were taken from solvent to reprotonate the catalyst. ${ }^{17}$ The terms anhydrous and dry will be used to indicate freshly distilled organic solvents (thoroughly used for all electrochemical experiments), without added Brønsted acids.

[17] F. Franco, C. Cometto, F. Ferrero Vallana, F. Sordello, E. Priola, C. Minero, C. Nervi, R. Gobetto, Chem. Commun. 2014, 50, 14670-3.

[18] H. Takeda, H. Koizumi, K. Okamoto, O. Ishitani, Chem. Commun. 2014, 50, 1491-3.

[19] H. Fei, M. D. Sampson, Y. Lee, C. P. Kubiak, S. M. Cohen, Inorg Chem. 2015, 54, 6821-6828.

[20] J.-D. Compain, M. Bourrez, M. Haukka, A. Deronzier, S. ChardonNoblat, C. Costentin, M. Robert, J. M. Saveant, B. Kumar, M. Llorente, et al., Chem. Commun. 2014, 50, 2539.

[21] J. J. Walsh, C. L. Smith, G. Neri, G. F. S. Whitehead, C. M. Robertson, A. J. Cowan, Faraday Discuss. 2015, 183, 147-160.

[22] J. Agarwal, T. W. Shaw, H. F. Schaefer, A. B. Bocarsly, Inorg. Chem. 2015, 54, 5285-5294.

[23] G. F. Manbeck, J. T. Muckerman, D. J. Szalda, Y. Himeda, E. Fujita, J. Phys. Chem. B 2015, 119, 7457-7466.

[24] F. J. Garcia Alonso, A. Llamazares, V. Riera, M. Vivanco, S. Garcia Granda, M. R. Diaz, Organometallics 1992, 11, 2826-2832.

[25] a) K. A. Grice, N. X. Gu, M. D. Sampson, C. P. Kubiak, Dalt. Trans. 2013, 42, 8498; b) D. Osella, C. Nervi, M. Ravera, J. Fiedler, V. V. Strelets, Organometallics 1995, 14, 2501-2505.
[26] a) D. H. Gibson, X. L. Yin, H. Y. He, M. S. Mashuta, Organometallics 2003, 22, 337-346; b) M. D. Sampson, J. D. Froehlich, J. M. Smieja, E. E. Benson, I. D. Sharp, C. P. Kubiak, Energy Environ. Sci. 2013, 6, 3748-3755; c) T. Morimoto, T. Nakajima, J. Am. Chem. Soc. 2013, 135, 16825-16828.

[27] S. C. Cheng, C. A. Blaine, M. G. Hill, K. R. Mann, Inorg. Chem. 1996, 2 7704-7708.

[28] J. Tory, B. Setterfield-Price, R. A. W. Dryfe, F. Hartl, ChemElectroChem 2015, 2, 213-217.

[29] P. Christensen, A. Hamnett, A. V. G. Muir, J. A. Timney, J. Chem. Soc Dalt. Trans 1992, 1455-1463.

[30] I. Azcarate, C. Costentin, M. Robert, J.-M. Savéant, J. Phys. Chem. C 2016, 120, 28951-28960.

[31] A. Basnet, P. Thapa, R. Karki, Y. Na, Y. Jahng, B.-S. Jeong, T. C Jeong, C.-S. Lee, E.-S. Lee, Bioorg. Med. Chem. 2007, 15, 4351-4359.

[32] F. Neve, M. Ghedini, O. Francescangeli, S. Campagna, Liq. Cryst 1998, 24, 673-680.

[33] M. Krejčik, M. Daněk, F. Hartl, J. Electroanal. Chem. Interfacial Electrochem. 1991, 317, 179-187.

[34] Frisch, M. J. et al Gaussian 09, Rev. D.01 2009

[35] a) S. Miertus, E. Scrocco, J. Tomasi, Chem. Phys. 1981, 55, 117-129; b) M. Cossi, G. Scalmani, N. Rega, V. Barone, J. Chem. Phys. 2002 117, 43-54

[36] a) A. D. Becke, J. Chem. Phys. 1993, 98, 5648; b) C. Lee, W. Yang, R. G. Parr, Phys. Rev. B 1988, 37, 785-789.

[37] a) F. Weigend, R. Ahlrichs, Phys. Chem. Chem. Phys. 2005, 7, 3297-305; b) F. Weigend, Phys. Chem. Chem. Phys. 2006, 8, 10571065.

[38] S. Grimme, S. Ehrlich, L. Goerigk, J. Comput. Chem. 2011, 32, 14561465. 


\section{Entry for the Table of Contents}

\section{FULL PAPER}

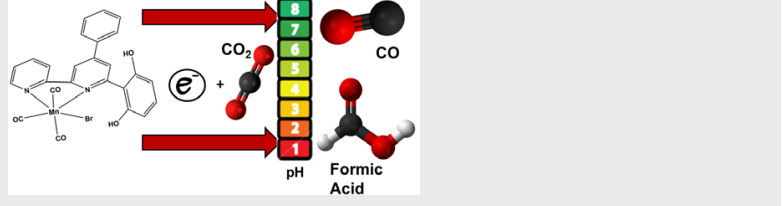

The electrochemical behavior of fac-[Mn(pdbpy) $\left.(\mathrm{CO})_{3} \mathrm{Br}\right]$ (pdbpy = 4-phenyl-6(phenyl-2,6-diol)-2,2'-bipyridine) in MeCN under Ar and its catalytic performances for $\mathrm{CO}_{2}$ reduction with added water, TFE and phenol are discussed. Bulk electrolysis reveals that the process selectivity is sensitive to the acid strength, providing $\mathrm{CO}$ and formate in different faradaic yields. The key role of the local proton source is demonstrated by a detailed spectroelectrochemical study under $\mathrm{Ar}$ and $\mathrm{CO}_{2}$.
Federico Franco, Claudio Cometto, Luca Nencini, Claudia Barolo, Fabrizio Sordello, Claudio Minero, Jan Fiedler, Marc Robert, Roberto Gobetto* and Carlo Nervi

Page No. - Page No.

Local Proton Source in the Electrocatalytic $\mathrm{CO}_{2}$ Reduction by $\mathrm{Mn}(\mathrm{bpy}-\mathrm{R})(\mathrm{CO})_{3} \mathrm{Br}$ Complexes 